\title{
發聲二件つ體壁共振，實驗的研究
}

\author{
Dr. Shintaro Nomura: Experimentelle Studien über die Mitschwingungen \\ der Körperwand bei der Stimmbildung.
}

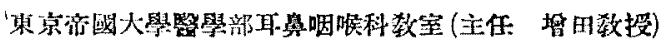
緊士野村新 太

目次

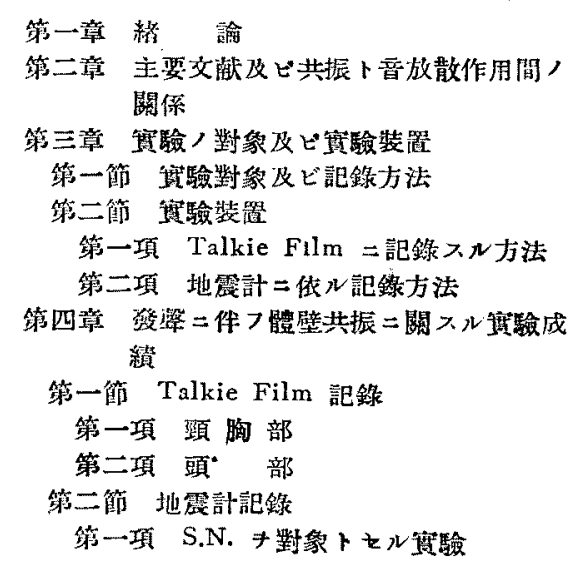

第一章 緒

人間が音整ヨ發スル際。そト同時二頭部。頸 部. 胸部等, 體壁が共振スルハ一般二識ラレテ キル事宽デアル。皆伊太利，唱歌呚師涬八低警 ノ際八胸部、高整デハ頭部が良っ振動スル事寛

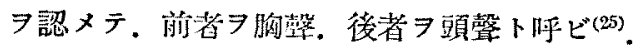

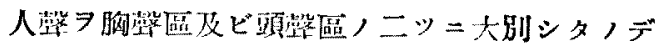
アル。聵壁，斯カル共振性二關シテ八其後多數

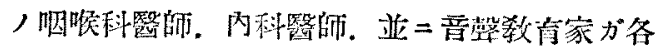

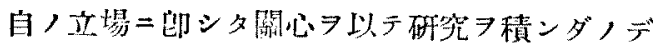

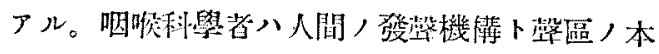

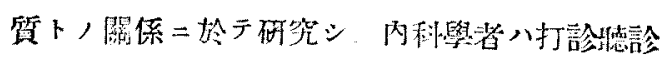

第二項 M.K. *對像卜七ル辣验

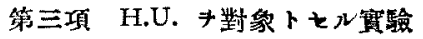

第四項 Y.S. キ對象ト七ル惯驗

第五章 總括

第一節 第四章第一節

第二節 第四章第二筬第一項，總括

第三笽 第四章第二節第二項 總括

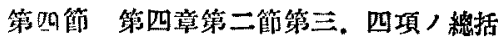

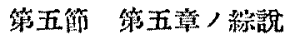

第空章 考 婪

第一篩 壁區卜，關保

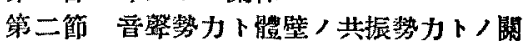
保

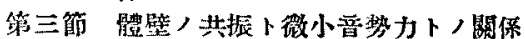
第七章 總 結 論 論

二際シテ胸部內䠞ハ如们ニシテ特殊ノ音习發

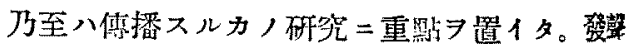

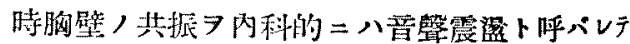
居几。畐聲呚商家八體壁，共振性卜歌馨，良 否. 就中體壁，共振八暗晊，美シサニ對シテ何 等カ寄與スルモ，リヤ否ヤフ識ラント努》 タ。

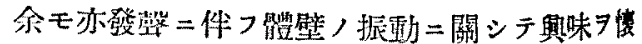

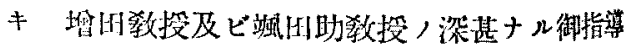
下二. 此主題二就テ梄驗 习報告スル二先ダチ，在來，文献八此主題习如 
何二取报ツタカ二就テ考察シ。共振. 其鳴及ビ 晋放散作用等, 意我习關明シ。本研究，因于起
ル理由习明カニセントス。

\section{第二章 主要文献及ビ共振，共鳴．至放散作用間ノ閶係}

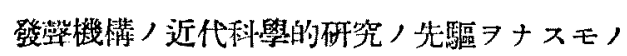
八佛人 Ferrein，假定ナり ${ }^{(8)}$ 。夫レニ依レバ

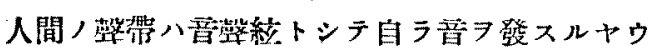
ニ振動スル。之振動ノ勢力八微弱ナルヨ以ラ體 壁八共鸣盤トシラ勢力

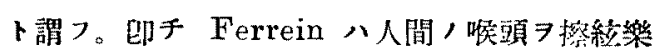

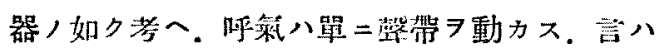

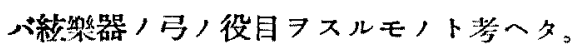

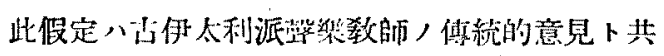

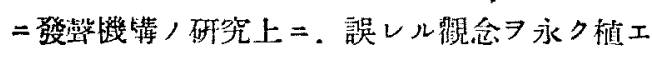
ッケタノデァル，然ル = 1862年 Helmboit:(12)

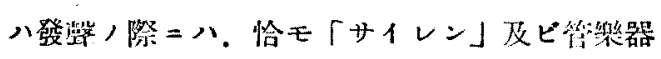

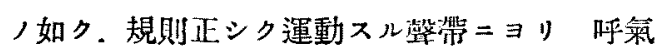
ガ週期的二腎斷サレテ舀波トナル事賽习初メテ

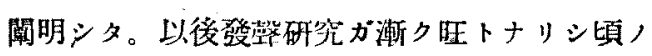
研究苩 ${ }^{(8)}$ デアル Brücke, Pussavant, Grätzner, Merkel, Bartb, Hennig (13) 等八知頍 7 管棌器卜 シテ解釋シタルニ不物。孰レモ依然トシテ體

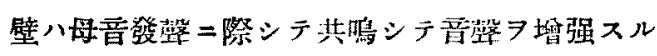
作用アリト考へタノデアル. MaljutiL(18)，如キ

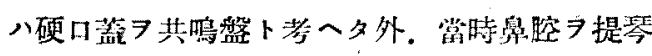
ノ $\mathrm{f}$ 形穴二粗勇スルト思惟シタ人タガ少クナカ ッタト言ハレル。

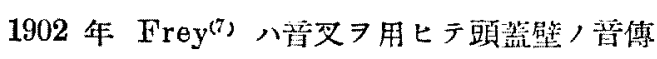
播性 ヨ筫驗シ之八Iwanof ${ }^{(18)}=ヨ$ リ追試確認》 レタ。其後體壁，振動篗域フ沚定セントスル苗 驗ガ相次デ行ハレタ ${ }^{(2 B)}$ 。1909 年 Hopmann 八

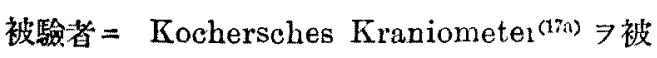

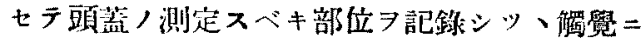
賴ツテ各母音發生中二於ヶル頭装臂，振動範圍 ヨ測定シタ。夫レニ依レバ語音「ア」八振動範 图最モ少ク.「イ」「ウ」八振動覀閣最大ニシテ 「エ」「オ」ハソ,中間 =位シテ振動範圍八各?

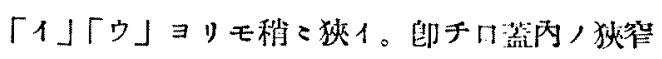

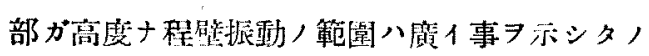
デァル(第 1 圆及ビ第 2 㘣)。
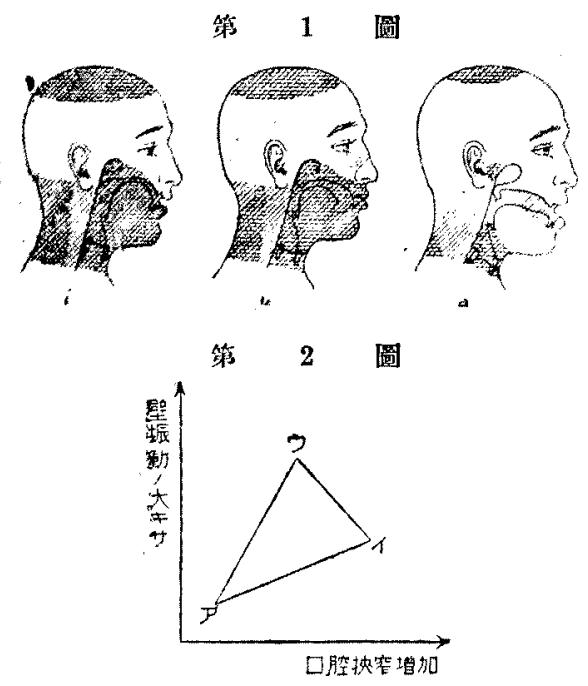

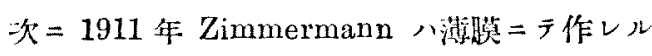

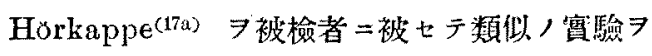

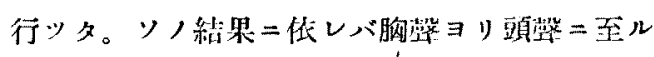
二從ッテ頭菣壁，振動八次第二減少シタ事が著 シィ。更= 1912 年 Stern ${ }^{(26)}$ 八聽崄器及ビ微番

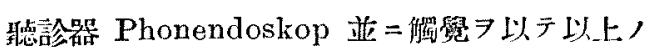
惯驗 フ追試シタガ大體ニ於テ Hopmanu，絬 果卜一致スルラ知ツタ。此際曋装习强メルト振 
動範園八增スガ夫レハ一定度二此マル， タ。彼八頭蓋壁，共振ト㢣區問題トア絬ビ附ケ

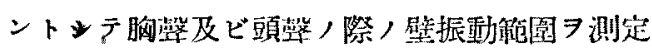
シ Zimmermann ト反龂/絬果 7 得夕。次二 Stern 八胸壁，振動测定シ。胸整，際八胸骨 柄ノ真下デ共振が最强ナルラ斷定シタ、此部位 八古伊太利愁派が正シ1 Appogiare la voce ノ際ノ重要ナ場所トシタモノデアル。而シテ彼

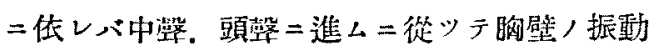
八弱マリ反對二頭蓋壁，共振八高マル。Katzenstein ${ }^{(17)}$ モ之二一致スル。Stern 八實驗，際二 八手ノ尺骨側が觸角最モ銃敏ナルモ。耳敚，皮 虏八最モ銃敏ナル故必要，際ハ之二賴り且ッ

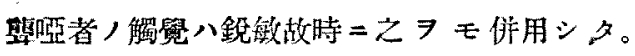
（指頭，䚚覺力二關スル研究八 R. Schwanner (1890), C. F. Thiel(1931), W. Trendelenburg 等ノ䔈驗フリ。振動ノ相對的研究＝際シテハ相 當ノ信賴习指頭二置イテ可ナルベシ)。Stern

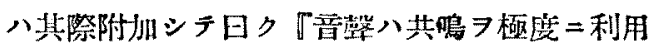
スル事二依ッテ響キ。之二依ッテ音韾八音色及

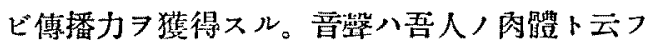
共鸣盤ヨリ成ル龙大ナ共鳴器

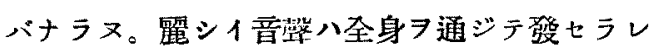
ルト言へル」ト，彼八共鳴，意莪八正當二理解 シタガ身嘈フ共矿器，壁卜考一タ事八事宽二即 シナイ點デアル。

1911 年 Giesswein ${ }^{(8)}$ 八「ガラス」圆㝆及ど切 離シタ頭篮习材料トシテ揆風器及ビ種タノ振動 數, 音丑

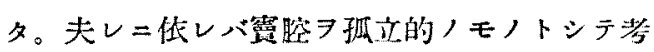
祭スル限り。夫夫レ八氣流=依ッテ固有振動》起 ス可能性ハアリト考へラレル。且ツ音整二依ツ

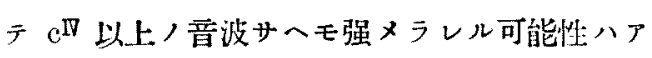

リトサル。彼八总つ「根本的誤謬八頭蓝骨/震 動 $\ni$ 以テ共鳴卜同意二解スル事. 或八胸壁/震 動习以基共鳴卜考へル事デアル』ト。斯ク Giesswein 八其鳴ト云フ現象

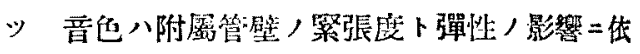
り變り得ルト考へタノ八注目スペキ事デアル。

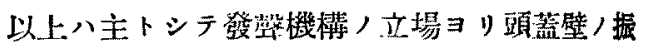
動フ諭ジタモノデアルガ內科學者力゙呼吸器咨㭧 , 診斷, 必要ヨリ胸部臟器亚二胸壁, 振動性 研究シタモ/亦少クナイ(1) - 即チ Wintrich, Skoda, Laennec, Selling 等主ナルモノデナ ル。ソノ後 1922 年 Martini(19)八正確ナ振動學 的理諭ノ下=胸壁ノ打診及ビ武診二就テ詳細十 ル研究ヨ發表シテ。队科的立場カラハ此閶題” 殆ド解決 7 見タ。彼ハ漏斗 7 胸部二虽テ數粨! 長サ, 管习以テ零姆被膜二此振怔习傅へ。 之 ア記錄シテ肺策胞，自己振動音域 $785-135$ Hertz ト沈定シタ。而シテ肺ノ打診音卜氣胞兽 ト八同一本態二基ク事 7 實證シタ。肺組織八彼 =低しハ音響學的二八多孔性，單一物質卜看儌 スラ得ベク，以上ノ自己振動領域八肺組織，彈 力性二由來シタモノデ容量二八關係シナ1恒數 デァル。從ツテ發整ノ際二八上記ノ音域二八肺 八强ク共鳴スルガ其以上，音域二於テ起ル蝐組 糡，强制振動八音ガ高マル程急激二減退スル筈 デアル。サレド胸警,特殊ノ音色卜胸壁/搎動 ト，關係二就テハ彼八何等言及シテ居ナ1。次

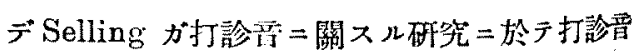
ノ極大值ハ $A=108$ Hertz デアルトシタハハ 上述，Martini，值ト一致スル。

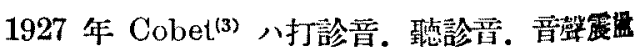
等 $尹$ 研究シ肺ノ自己振動數 $7 \mathrm{~A}-\mathrm{e}=100-130$ Hertz トシタ。彼八 Palmophor ト称スル自 
慗, 留置 =85-170 Hertz 閒二於テ之が最モ强イト述べ タが之八 Martini /場合卜大差が+1。又之 $\Rightarrow$ Riengersches Kondensatormikrophon $\Rightarrow$ 用七テ記錄シタル=基音が大部分デ第二倍音以 上ハ $10 \%$ \%下トナッテキルョ見タ。1928 年

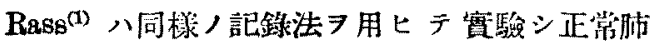
氣胞音/特徽音域ハ 150-400 Hertz ダトシタ。 併シ彼八他，實驗(2) タ行ッタ。郎于電話器裝琶 デ出シタ單音ヨ音ノ淵レナイ管二通ジテえタ ロ中二入レ此際ニ胸壁ヨリ出タ音ヲ Rieggersches Kondensatormikrophon =揆䚺記錄 = 現ハシタ。夫レニ依レバ 90-400 Hertz，單 音习造ツタ時胸部ハョク振動シ。此共振ハ 190 Hertz，時最大值 $フ$ 示シタ。

1925 年 Giesswein ${ }^{(9)}$ 八種方程度，彈力习 持ッタ物質 用七テ. 昔叉及ビ选風器 數ヨ测定シ彈性。管長及ビ管，厚等卜，關係 ヨ考究シテ後人間，氣管枝，自己振動數八話繁 昔域，下端二相當スルト諭ジ音馨振温，原因 ＼cjkstart氣管枝，共鸣二求メタ。

以上ノ交献 究二二種ノ異ナル傾向习看取スル事が出來ル。

1) 內部組織，固有振動數 7 测定シ以テ鲑壁 ノ最强共振晋域习決定セントスルモノ。

2）體壁自身，共振ノiフ测定シタルモノ。 新レノ立場ヨリ諭ズルモ在來，文献二於方實 祭上二モ甚ダシィ不一致 振動域八以上ノ文献 $コ$ 大體 90 -400 Hertz, 其最大振動域八 100-135 Hertz 間ニアリト云 フテ差支へナ1。

而シテ發㢣二際シテ肺ガ固有振動
スル現象ト。えガ體壁习振動セシメル時其影響 ガロヨリ出ヅル音韾こ及ブ程大ナリ否ヤ ト 八稍に異ナレル問題二屬スル。結局，主題八共 鸣卜共振卜ノ敦レニ關セズ體壁が留シテ. 恰カ

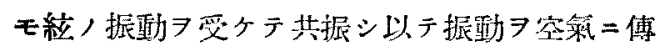

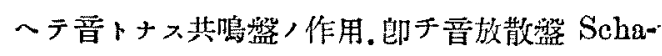
llabstrahJer デアルヤ否ヤ二歸着スル。 1929 年 Tondort(29) ガ「口裂八人間, 渻器= 於テ八音放散ヨナス作用. 郎于提琴，胴，役目 ヨスル。共鸣卜曋放散トハ關係がナ1』ト言ツ タ人八雄ル重要ナ事デアル。何トナレバ共振が 物醴，固有振動域二起ツテ振幅大ナル場合

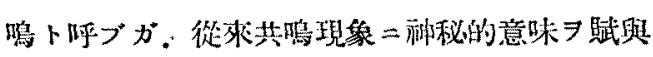
シ發簘生理學上二多ク，誤解习招イタ故デア ル。共鳴器が周園音場，音謷力フ吸收シテ强け 音䭒ヲ發シ。或ハ音叉が共鳴箱二取付ケラレテ 音が急二强マル等，現象，理解二際シテ共鳴

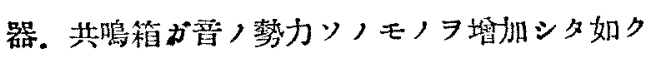
解サレ易イ。事實八以下，如クデアル。共鳴器 习持來儿時八音場二廣ク分散シテ居タ意勢力八 共鳴器二吸收サレテ 共鳴器，方向二集合スル ノデアル (Rayleigh) (23)。音叉フ共唯箱二取付 ケルト長イ時間ヨ費シテ使用サルベキ曋叉，勢 カガ共鳴箱二傳ツテ早䈍二使用シ翗せレテ一時

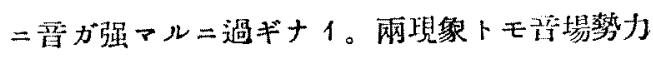
，總和二八變化ナ夕，共鸣八前者デ八空間的. 後者デ八時間的×音势力が澴縮シラ゙起ッタ現象

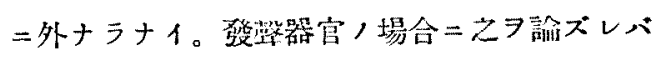

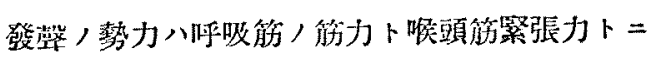
ヨッテー䉝的二決定サレル管デアル。然ル二身

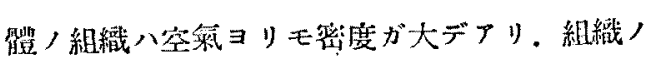
共振 ヨ來タシテ後結果トシテ體壁二振動が現い レそガ再ビ空氮，振怔习迎シタト考へテモ。 
畐が組織二入射ノ際及ビ組織自身ヨ振動セシメ ル䉆。消失シタ勢力ハ決シテ少クナ1。辛整が

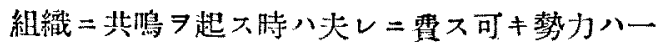
居大ナル揁失トナル。即チ理諭的二論ズレバ音 㢣ト體組織ノ共振卜ハ相助タ合ハズシテ却ツテ 共通，勢力フ奪七合フ立場ニアル事が明カトナ

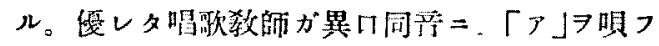

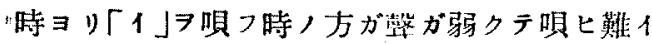

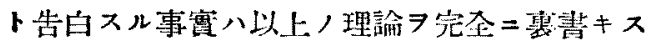
ルモノデアル。何トナレパ「ア」ア發㢣/際八附

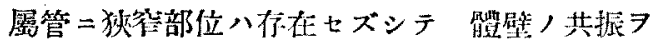

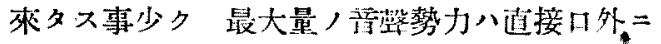

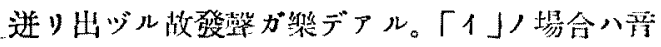
八體組繰二多ク吸收サレテ弱マリ。逆二發㢣ハ 難シクナル。1932 年 Husson u. Tarneaud モ壁

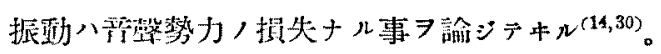

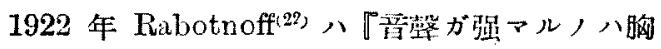
壁，振䡃=依ツテ起ルトスルノ八許容出來ナ 1。歌于ハタト一外套フ䌒ツテモ同一，强サデ

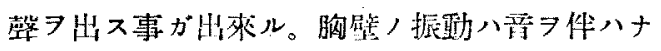
1震動デアル」ト論ジタ。さハー隹光モデアル

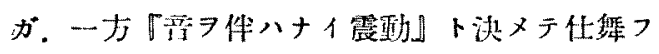
ノ八誤リデアル。又 1934 年 Forchhamme1 ${ }^{(6)}$ 八『振動體, 共振が售丈ハソノ一部习强メ儿時

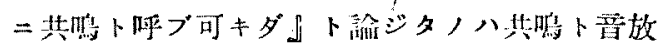

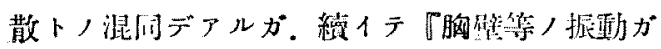

空莱．身體，空氣ト二重傳播ニ外ナラナイカラ 共鳴デモ紊，增强デモ+1。單二內腔=强1搌 動がアル證據デアル。即チ之八勢力ノ損失デァ ル。損失 7 避ケルニ八口中=不用ナ狄窄部 7 作 ラナイ事デフル』ト諭ジタ。此内容八正シイ。 脌シ斯カ儿壁振動が再ビ空氣二傳播サレテ相獣 有力ナ暜トナルヤ否ヤ八害際，测定ヨ待タズン

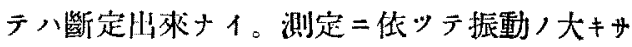

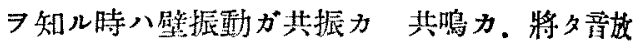
散ノ役割 ル。位ッテ余八今後乙ヨ詳逃セントスルモ/デ 厂ル。

份木輓近 Trendelenburg(30)， Selenmikrophon 及ビ Rieggersches Kondensatormikro"

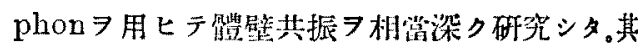
絈諭トシテ最後二次ノ如ク述べテキル。如チ。

1）頭筧壁卜胸壁二於テ八振動八單絃振動デ アル事が多1。即チ先ヅ音が踓壁ヨリノ音放散 二任ツテ强メラレ得ルト七バ夫レ八整，基音デ アラウ。

2) 鼠竞が艋等ヨリ放散サレル程度八時二侮

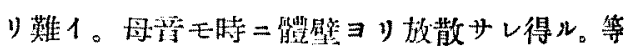
ア述ベランル。サレド末ダ此主題=基礎的解答

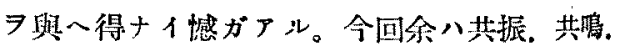

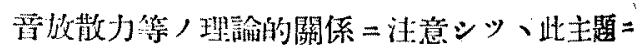
就テ努力七ントスル所以デァル。

\section{第 三章＼cjkstart惯驗ノ對象及ビ實驗法}

\section{第一節 實驗對象及ビ記錄方法}

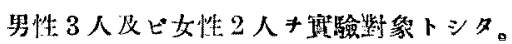

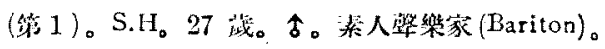

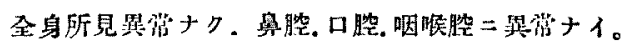
身長 $163 \mathrm{~cm}$ 。體重 $55 \mathrm{~kg}$. 體表酒辞 $16334 \mathrm{~cm}^{2}$ (後
出高比泉氏(28)，部算法二依儿)。

(第 2)。S.N. 30线。古。泫人㢣然家(Tenor)。余

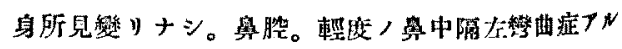
他口䏶，咽喉腃二罢常ナシ。身長 $163 \mathrm{~cm}$ 。體重 51 kg. 體表面栍 $15476 \mathrm{~cm}^{2}$ 。 
(第 3 )。M.K. 氏。 34蔵。古。Tenor 歌手。東京部

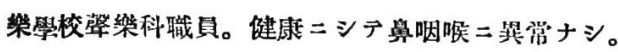
身長 $165 \mathrm{~cm}$ 。體重 $70 \mathrm{~kg}$. 體表面辕 $17863 \mathrm{~cm}^{2}$ 。

(第4)。H.U. 氏。22蒇。早。Soprano. 東京畐樂

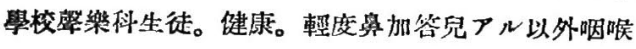
ニ異常ナシ。身長 $153 \mathrm{~cm}$ 。體重 $48.5 \mathrm{~kg}$. 體表面 積 $14470 \mathrm{~cm}^{2}$ 。

(第 5 )。Y.S. 氏。21蔵。早。Mezzosoprano。東京 吾樂學校㢣樂科生徒。健康. 悬咽啹二異常ナシ。身 長 $156.8 \mathrm{~cm}$ 。體重 $55 \mathrm{~kg}$. 體表面槕 $15538 \mathrm{~cm}^{2}$ 。

(第 1 ) ニ於テン医電氣利用をル pick-up 體 表こ輕ク押シ當テッ、胸綮 $\mathrm{g}=192$ Hertz 及ビ頭㢣

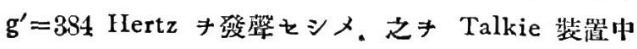
二䓕キ. 濃淡式 Talkie Film トシテ記錄シタ。

(第 2) 乃至(第 5$)=$ 於广 八石本式小形地震訣

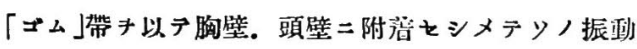
キ地震計ノ振動. 更ニッノ小鏡ノ迴轉二移シ. 更二 之キ光學的槙杆デ麻大シテ感光紙二記錄シタ「ゴム」

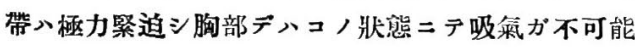
ノ程度二締メ．頭部デ八輕イ頭痛キ催入程度二祭䋠 スル。咸力八 Tycos 血茞計キ體壁卜「ゴム」帶間 二挿入シテ測定をル結果 $1.333 \times 10^{6} \quad \mathrm{Lyne} / \mathrm{cm}^{2}$ 程

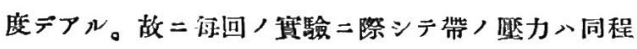
度卜見竞菠へナイ。

實驗ニ際シテハ 1 Oktav 7 長三度三三等分をル $c=$ 128 Hertz, e $=160$ Hertz, gis $=204$ Hert $z, c^{\prime}=256$ Hertz, $\mathrm{e}^{\prime}=320$ Hertz, gis ${ }^{\prime}=407$ Hert $z$ 等 /調子干 選ンダ。份本必要二應ジテ $\mathrm{A}=108$ Hertz, $\mathrm{b}^{\prime}=456$

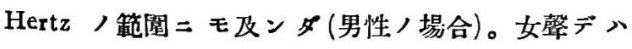
$\mathrm{g}=192 \mathrm{Hert} z, \mathrm{~g}^{\prime \prime}=767 \mathrm{Hertz}$ 間八三度音階キ用七 ル事ニシタ、晋㢣入各唱者ノ能力二應ジ强㢣 ( f )

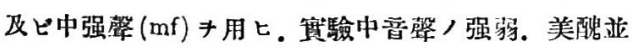
二光箱中/迴轉鏡キ眺メッ、振幅等/關保キ監視シ ッ、感光用紙ニ記錄ナナサシメタ。

\section{第二節 實驗裝置}

\section{第一項 Talkie.Film 二記錄スル方法}

第3 圖八篚者人传用セル理研式研究用「トーキー」 錄吾機テアル(27)。右上前面錄吾部. 右下同 Film 远

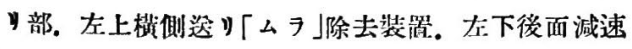

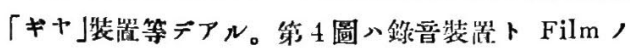

第 3 圆

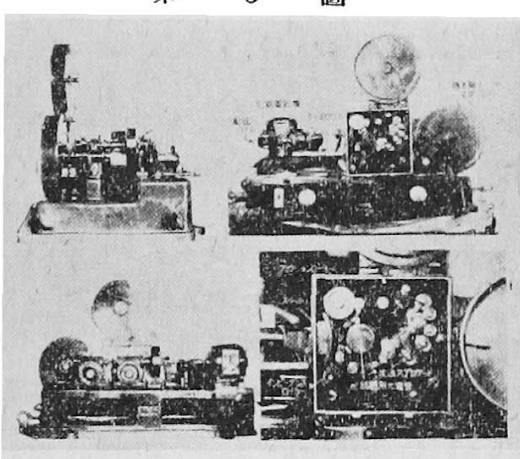

運吩卜ノ關係キ示入。

箐 4 圖

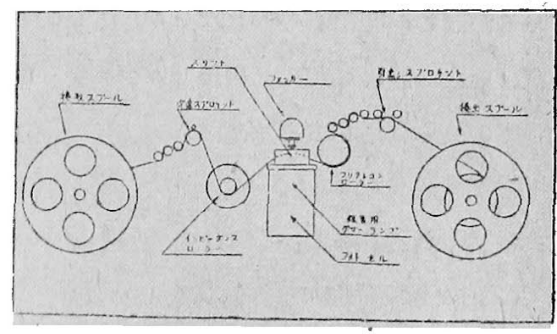

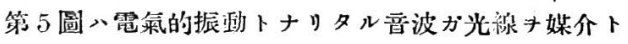
シテ Film 錄部サレル过ノ經過キ圖說七ルモノデ $r ル$

第 5 圖

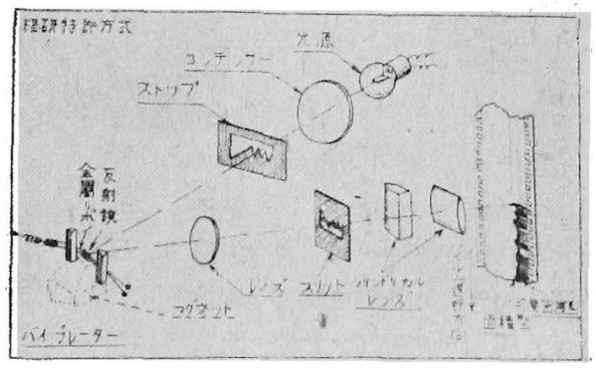

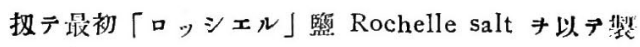
作七ル医電氣性 Pick up 二依ッテ可检振動力゙霄流 八振動二變化サレテ光源タル glow lamp こ至ル。 glow lam $\mathrm{P}$ 人光力八霄流, 强弱二站行スルキ以テ 此光力八綎化筑 5 圖，如クシテ Talkie Film 上二濃淡ノ縞トシテ錄畐スル。Film, 速庭ハ往秒

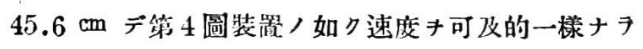
シムルャウエ夫サレティル。

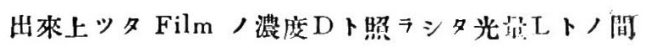


$=$.

$$
\mathrm{D}=\log \left(\frac{1}{\mathrm{~L}}\right)
$$

ナル關係アリ。此關集入音，Sensation level 卜畐 儿暨力ノ大キサトノ關保二相當スル。而シテ此錄音 装置ハ田口工學士ニ依レベ55-6000 Hertz 閅デ 八. 其特性曲線ガ略了直線狀キナストサレテキル。

\section{第二項 地震計二依ル記錄方法}

\section{（第一）地霞計ノ外䚉及ビ搆造。}

余八使用七ル石本式小形地霞計入石本㸚授ノ御好 意二依リ特二製作二成功シタル世界最小八變位地震 計デアル。從ツテ其篎造及ピ理論二就テ未ダ詳細ナ ル說明キ成百二見出フ能ハプ。依テ余自ラ計算をル 結果キ稍了偝細二亘り揭載スル。

第 6 圆

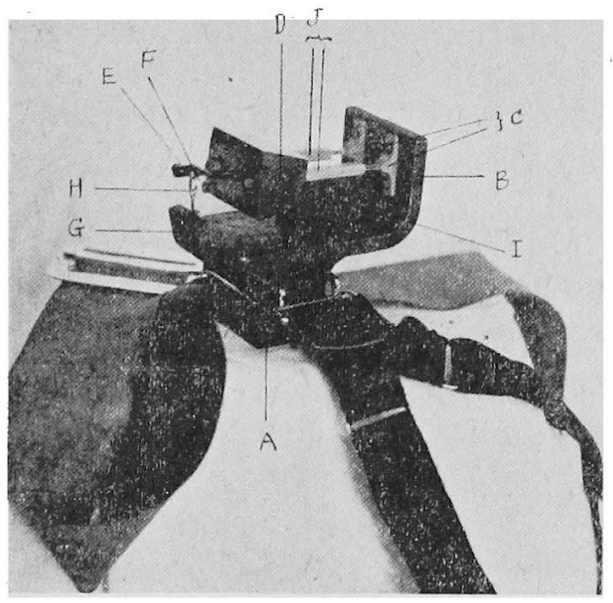

第 7 圆

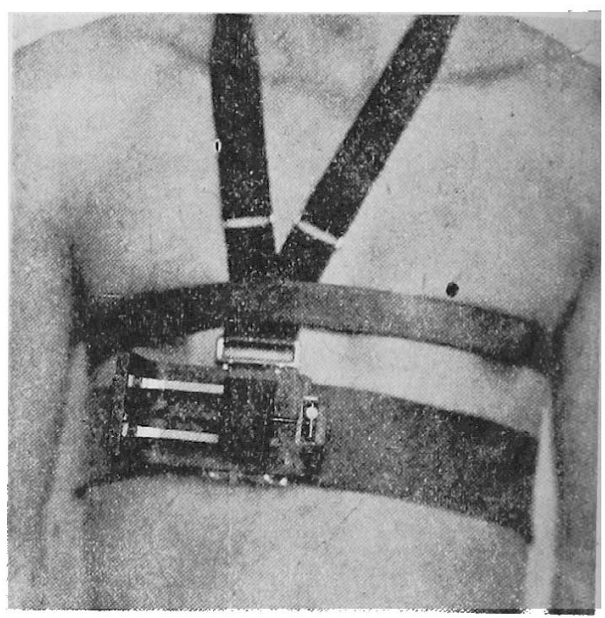

ニハ劣木殆ド静止スル。故二底 $\mathrm{A} ヨ$ リ出タ他翼 $\mathrm{G}=$ 取付々タ馬蹄形小磁石Hト。 Ṕivot Eトキ接解七シ ムレバ初メノ瞬間ニハHノミ動キPivot $\mathrm{E}$ 八殆F 此シ居ルキ以テ. $\mathrm{H}$ 㘘位ハ $\mathrm{E} \neq$ 迴轉スル運動 變化シテ小鏡八迴轉スル。後者ノ運動 $キ$ 光槙杆 $=3$ リ搌大シテ感光峨二記錄スル。細長キ容器I八振子 Dノ下側面 $ョ$ ソ出デシ金屬板制振器 dämpfer キ容 ル、些挛キ藏入。之二油キ入レテ Oil damperトス ル事ガ出來ル。

以上 3 日明カナル如ク地震計ノ主要部分ハ賽二其 振子及ビ振子附屬物 こアル故此部キ圖解スレバ第 8 圆ノ如クナル。同上圖入侧面 $ョ$ リ. 同下圆へ下 第 8 圆

此地震計ノ高 サ $8.2 \mathrm{~cm}$, 長廿 $10 \mathrm{~cm}$, 幅 $5 \mathrm{~cm}$, 重サ $475 \mathrm{~g}$, 振子 及ビ附屬物/重虽》2 $255.7 \mathrm{~g}$ 。第 6 圆二於テ底 $A$ *以テ體壁二密蓓 スル。底 $\mathrm{A}$ 八面剩 $5 \times 4 \mathrm{~cm}^{2}$ 。之二 續ケルー疽 $\mathrm{B}$ ハ支點部 C キ据ツテ 地震計〉主要部タル振子 $\mathrm{D}$ キ支人 ル。振子 D / 底面中心 $ョ$ y棒キ出 シテ小軸 Pivot $\mathrm{E}$ キ擔七. $\mathrm{E}$ 八 㨁坙 $4.5 \mathrm{~mm}$ ノ小鏡 $\mathrm{F}$ 有ショ 自由二备轉スル。小鏡八四面鏡キ ナシ其焦點距踓ハ $30 \mathrm{~cm}$ デアル。 今床 $\mathrm{A}=$ 一定ノ變位アリタル時振

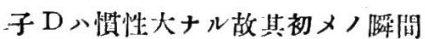

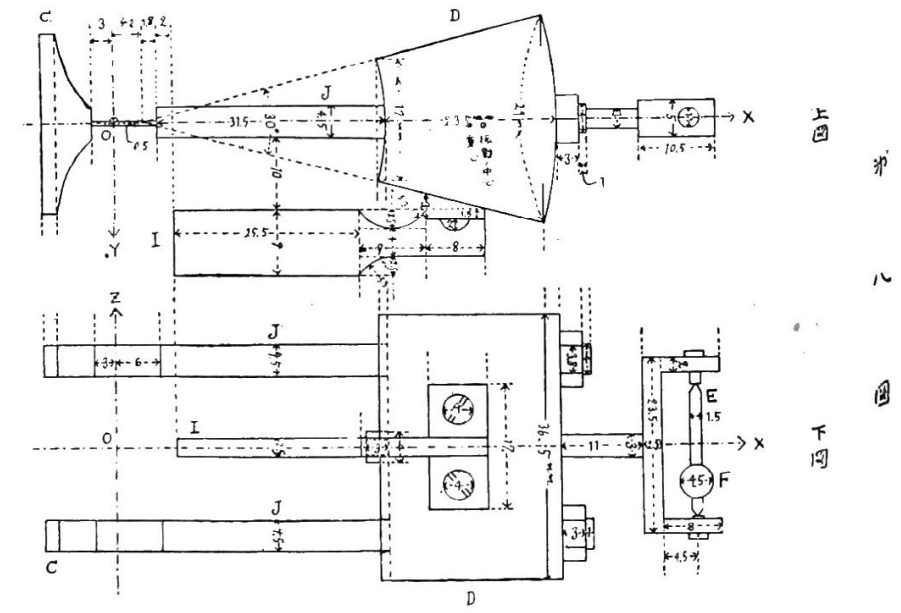




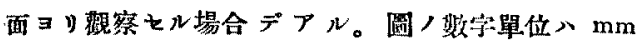
テアル。舀木地震計ノ材料二就テー言スレパ底二

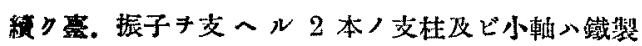
(郎子 A,B,E,J 等. 比重 7.86). 振子自身八鉛棐(比 重 11.34)之テ畚鍮二テ薄ク被七タルモノデアル。

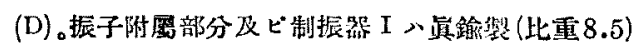
デフ。

\section{（第二）重心，惯性能率及ビ垢動ノ中心}

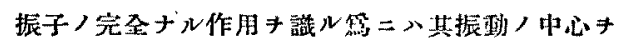
決定スルキ要スル。其篦二第 8 圆二於々ル如ク振子 附屈部分キ棓算ショキャウ16 小部分二細分シ. 支

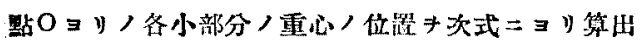
シタ。

$$
\text { 重心 } \bar{x}=\frac{\iint_{s} x d x d y}{S}, y=\frac{\iint_{s} y d x d y}{s}
$$

$\mathrm{S}$ 八 $\mathrm{XY}$ 面二投射之心备部分八面程。文支點 $\mathrm{O}$ 八 理諭上振子支持棒 $\mathrm{J}$ 人独部郎チ板登修部二於テ C $=$ 近 $\neq 1 / 3$ 等分點 $=\boldsymbol{T}^{*(15)}$ 。

賣性能率。各小部分，重心二閣シ $\vec{r}$ 八其惯性能率 $\mathrm{J}_{\mathrm{g}}>$

$$
J_{g}=c \iint\left(x^{2}+y^{2}\right) d x d y
$$

但 $\mathrm{c}$ 八各部分，密度。之*支點 $\mathrm{O}$ ヨy/惯性能率= 换算スレパ Steiner，定理 ${ }^{(20)}=$ 依y

$$
\mathrm{J}_{0}=\mathrm{Jg}_{\mathrm{g}}+\mathrm{Mih}^{2} \mathrm{i}
$$

$\mathrm{Mi}$ 八各部分/留量. hi 八各重心卜支點O間/距離 デプ。

体ツテ振子及ビ附䨞部キ一緒ニシタ全體ノ重心ノ位 唯》

$$
\begin{aligned}
& \mathrm{X}=\frac{\sum_{0}^{16} \mathrm{Mixi}}{\sum_{\Sigma}^{16} \mathrm{Mi}}=48.695 \\
& \mathrm{Y}=\frac{\sum_{0}^{16} \mathrm{Mi \overline {y }}}{\sum_{0}^{16} \mathrm{Mi}}=0.579
\end{aligned}
$$

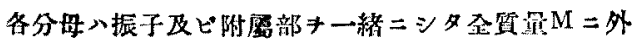
ナタズ。故二支點Oト重心卜ノ距離 $\mathrm{H}$ 人

$$
\mathrm{H}=\sqrt{\mathrm{X}^{2}+\mathrm{Y}^{2}}=48.698
$$

\section{及全能/怚性能率 J 入}

$$
\mathrm{J}=\stackrel{1}{\Sigma}_{0}^{15} \mathrm{~J}_{0}=633225000\left(\mathrm{mg}, \mathrm{mm}^{2}\right)
$$

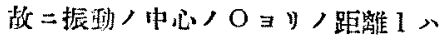

$$
\mathrm{I}=\frac{\mathrm{J}}{\mathrm{I} \mathrm{M}}=50.857
$$

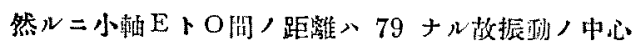
ニ於ヶル變位ハ小鏡ノ部デハ

$$
\frac{79}{1}=1.55^{3 \mathrm{~s}} \text { 倍 }
$$

ダケ摭大サレル。

\section{（第三）地茼計桭子ノ橾動}

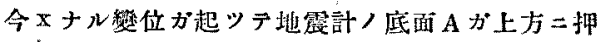

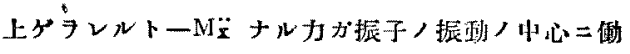

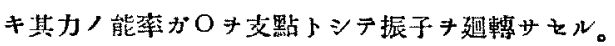

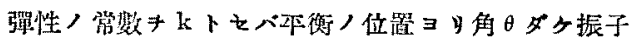
ガ振レタ時. 之キ元二㞔サントスルカメー $\mathrm{k} \theta$ 。文制

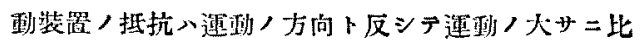

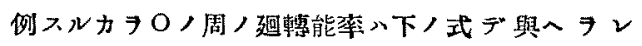
N.

$$
\mathrm{J} \ddot{\theta}=-\mathbf{k} \theta-2 \mathrm{R} \dot{y}-\mathrm{Ml} \ddot{\mathrm{x}}
$$

简單, $又 \frac{\mathrm{k}}{\mathrm{J}}=\omega^{2}, \frac{\mathrm{R}}{\mathrm{J}}=\gamma$

トマバ前式ハ

$$
\ddot{\theta}+2 \gamma \dot{\theta}+\omega^{2} \theta=-\frac{\mathrm{M}]}{\mathrm{J}} \ddot{\mathrm{x}}
$$

單純ナル場合トシテ $\mathrm{x}=\mathrm{L} \operatorname{cospt}$ ナル單絃運動ナル 時入式 (2)八解入

$$
\begin{aligned}
\theta= & A e^{-r t} \cos \omega^{\prime} \mathrm{t}+\mathrm{Be}^{-\mathrm{rt}} \sin \omega^{\prime} \mathrm{t} \\
& +\frac{\mathrm{Ml}}{\mathrm{J}} \frac{\mathrm{L} \mathrm{p}^{2} \cos (\mathrm{pt}-\mathrm{p})}{V^{\prime}\left(\mathrm{p}^{2}-\omega^{2}\right)^{2}+4^{\mathrm{Y}^{2}} \mathrm{p}^{2}} \cdots \cdots
\end{aligned}
$$

$$
\text { 但 } \omega^{\prime 2}=\omega^{2}-\gamma^{2}, \varphi=\tan ^{-1} \frac{2 \mathrm{rp}}{\omega^{2}-\mathrm{p}^{2}}
$$

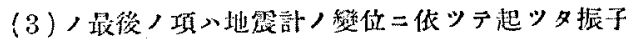
八强制振動キ表ハス。

$$
\begin{gathered}
\mathrm{P} \gg \omega \\
\text { ナル時ハ } \gamma^{2},\left(\frac{\omega}{\mathrm{p}}\right)^{2} \text { 等ハ小サイカラ略サレテ } \\
\theta=\frac{\mathrm{Ml}}{J} \mathrm{Lcos}(\mathrm{pt} \text { - } \mathrm{p})
\end{gathered}
$$

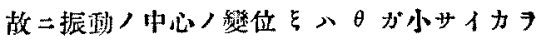

$$
\begin{aligned}
\xi & =1 \sin \theta \doteqdot 1 \theta \\
& =\frac{\mathrm{Ml}^{2}}{\mathrm{~J}} \mathrm{~L} \cos \left(\mathrm{p}^{\mathrm{t}}-\phi\right)
\end{aligned}
$$

之八朱ノ振幅二 $\frac{\mathrm{Ml}{ }^{2}}{\mathrm{~J}}$ 乘ジモノデアル。即チ地震 
計/周波特性曲線入 $\omega \gg \mathrm{p}$ 人場合二八正線狀 ス。之 Mikrophon トノ藷シキ對照點デ後者ノ如ワ 固定サレタ振動計デ八其自己振䟭数キ出來ルダタ 上ゲル事ガ必要デアルガ. 地震計ノ如ク床卜共二自 习運動スル振動計デハ自己振理数キ低メテ夫ョタ遥 カ二高亿振動数キ訅錄フルト特性曲線力证線狀二近 ッ゙ク。

\section{（第四）擴大裝置}

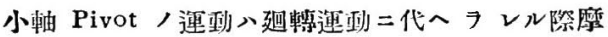

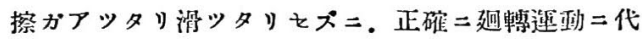
ヘタレル管二馬踇形小磁石，一脚 $\mathrm{H}$ 二小軸子接触七

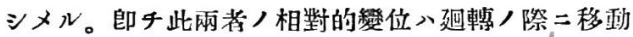
シタ小軸ノ周 (圆弧) ノ長サ二等シイ。即チ小軸/直

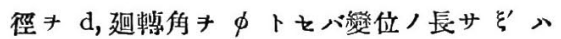

$$
\xi^{\prime}=\phi \frac{\mathrm{d}}{2}
$$

鏡面ガ 人移動ハ $2 \phi$ デアル。小鏡. 感光面阔/距激キ $\mathrm{S}$ 卜 シ. 反射光線二臬角二面シタ感光紙二記錻:サレル光 線軌跡ノ變位キ艺”マぐ

$$
\xi^{\prime \prime}=\mathrm{S} \sin 2 \phi \fallingdotseq 2 \mathrm{~s} \phi \cdots \cdots(6)
$$

(5)，（6）八此八小鏡丮用七夕搌大裝置 $=ヨ ル$ 倍率 $\mathrm{V}_{0}$ テアルカタ

$$
\mathrm{V}_{0}=\frac{\xi^{\prime \prime}}{\xi^{\prime}}=\frac{4 \mathrm{~S}}{\mathrm{~d}}
$$

即于距踓二比例シ小軸ノ太廿二反比侧スル。 余/使用そル地震計デハ振動/中心二於タル變位キ そトセパ $(1)=\Xi リ$

$$
\frac{\xi^{\prime}}{\xi}=\frac{79}{1} \doteqdot 1.5534
$$

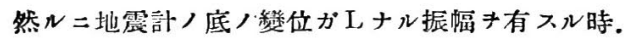

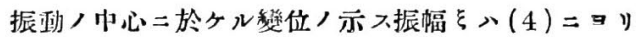

$$
\xi=\frac{M 1^{2}}{J} \mathrm{~L}=1.0444 \mathrm{~L}
$$

賽驗ノ際ニ八感光紙キ小鏡 $\mathrm{S}=70$, 又小軸 / 拄潩 $\mathrm{d}=1.5 \mathrm{~mm}$, 從ツコ全體/倍 奉V $、(7) .(8) .(9) \equiv$ y

$$
\mathrm{V}=\frac{\xi^{\prime \prime}}{\mathrm{L}}=\frac{\xi}{\mathrm{L}}, \frac{\xi^{\prime}}{\xi} \mathrm{V}_{0}=3028 \text { 倍 }
$$

即于感光紙, 曲線/振幅》賽際/振幅, 3000 倍卜 看做シテョイ。

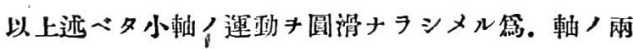

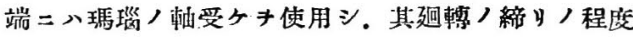

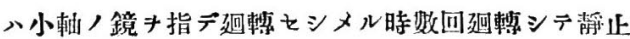

スル程扊ニスル(15)。(第 9 圖)。

第 9 圖

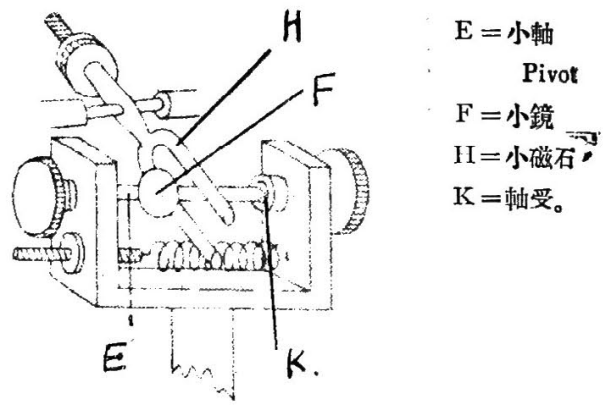

光學的槙杆トシテハ横河式 Oscillograph/附㬝光 箱 Optical box *使用シタ(第 10 圖)。

第 10 圖

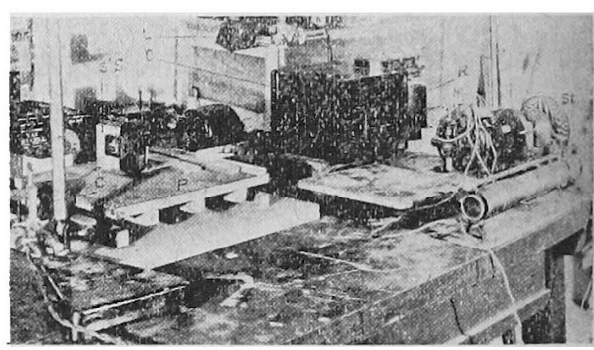

第 11 圖

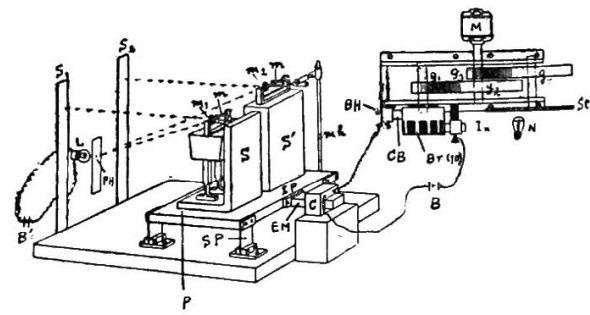

第 10 圖及ビ第 11 圖/說明

(A) 振動測定二關スルモノ。

$\mathrm{B}^{\prime}$ 電燈用電池。 IP 驖板。 $\mathrm{L}$ 電燈。 $\mathrm{m}$ 小紐石。 $m_{1}, m_{2}$ 小鏡。 $m h$ 磁石支持架。O横河棐光箱。 $P$ 振玫板。PII ピン穴。R迴轉子。 $\mathrm{S}$ 地震計。 $\mathrm{S}^{\prime} \mathrm{mg}$ キ载セル熟。 $S_{1} S_{2}$ 「ガタス製目盛尺。SP發條板。

(B) 勵動装幒二閣スルモノ。

$\mathrm{B}$ 電池。BH刷子㨦子。Br 刷子。C 磁石コイN。 CB 炭素刷子。 EM 電磁石。 $\mathrm{g}_{1}, \mathrm{~g}_{2}, \mathrm{~g}_{3}, \mathrm{~g}_{4}$, 萃車 $\left(\mathrm{g}_{1}=\right.$ $\left.\mathrm{g}_{3}, \mathrm{~g}_{2}=\mathrm{g}_{4}, \frac{\mathrm{g}_{2}}{\mathrm{~g}_{1}}=4\right)$ 。. In 絕緤體。M需政機 $\left(\frac{1}{16}\right.$ 馬 
力。1 分間迴轉 1400 回运) トロポスープ」。

\section{(第五) 性能苗駼。}

上逝ノ橉造及ビ理論二依、製作サレタ余ノ地震計 ガ筫際使用二際シ所期ノ如キ性能き筑揮スルヤ否中 キ硫メルタメー定裝㯰キ以テ赛驗キ行ツタ。第10圖

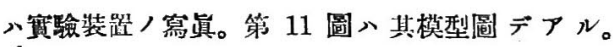
惯驗原理入雨图二示入如クーツノ本面板 $\mathrm{P}=$ 地震計 $\mathrm{S}$ 及ビ板自身ノ振動キ觀察スル所ノ鏡及ビ磁石

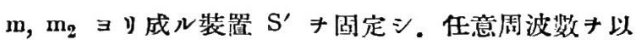
テ板 $\mathrm{P}$ キ振動シツ、地震計及ビ板ノ振動ノ關係キ識 ルノデアル。斯クテ起サレタ鏡 $\mathrm{m}_{1}, \mathrm{~m}_{2}$ /廻䡔運動
* Pinhole PIH *通ジタ點狀光線ナ媒介トシテ「が $\exists$ 入製目盛 $\mathrm{S}_{1}, \mathrm{~S}_{2}$ テ計測スル力迴轎子 $\mathrm{R} 中=$ 然 イテアル感光紙二訅䟿セシメル。

振動板 $\mathrm{P} \leadsto 4$ 枚, 銅鐵製板發條 (厚サ $1 \mathrm{~mm}$ ) * 以

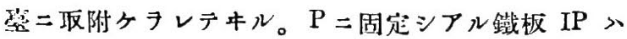

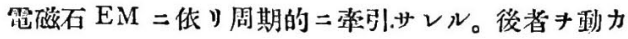
ス電流ハ電池 $\mathrm{B}(10000$ Volt $)$ ョリ出タモノデアル。 此電流八電劺機 M. 齿車 $g_{2}, g_{1}$ 认ビ Ebonite デ等

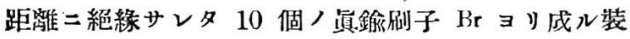
㟟キ以テ每秒 1000 回迄周期的二遮斷シ得儿。一方 遮断回數》齿車 $g_{3}, g_{4}$ デ連絡シタ Stroboskop St キ讀ンデ自在二加減出來ル。

圆

(a) $110 \sim$

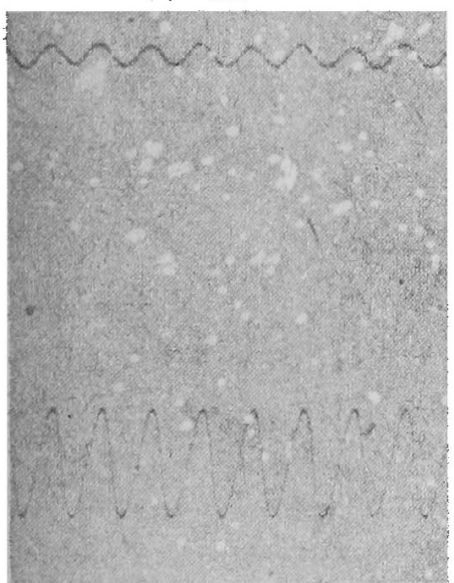

第

(b) $260 \sim$

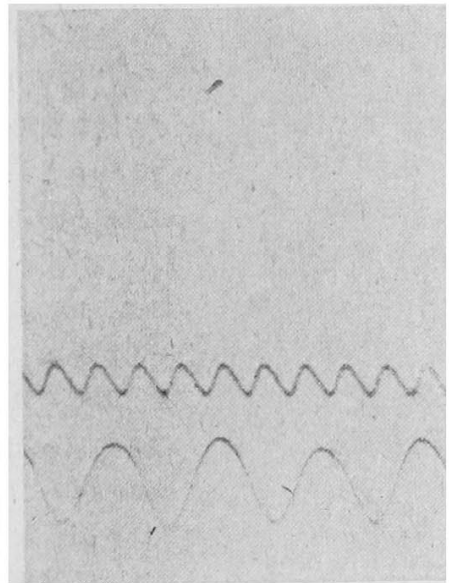

圆 (c) $350 \sim$

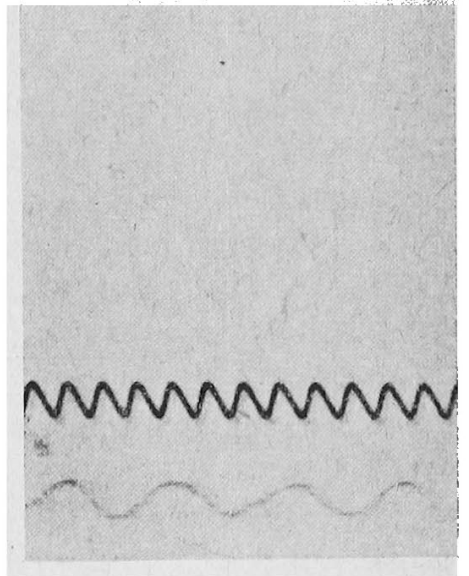

(a) $40 \sim 1$

(b) $200 \sim$

(c) $550 \sim$

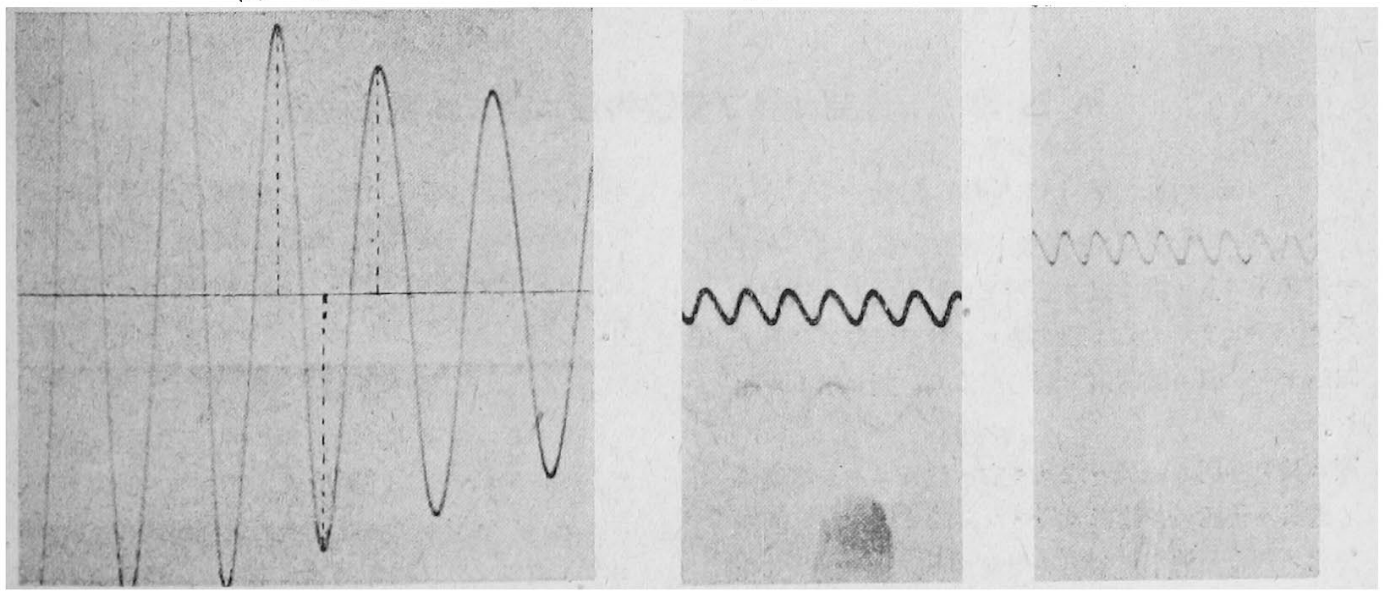




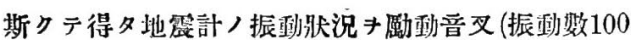
Hertz そモノ) /振動卜共二記錄セバ第 12 圆及ビ第 13 圆 (b) (c) ノ如クナル。文電動機ノ廻轉数キ連續的二 移動シテ板ノ振動ノ大キサ及ビ地震計ノ振動ノ大キ サキ記錄セパ第14圖キ得ル。圖デ下方，曲線ハ板

第 14 圆 (a)

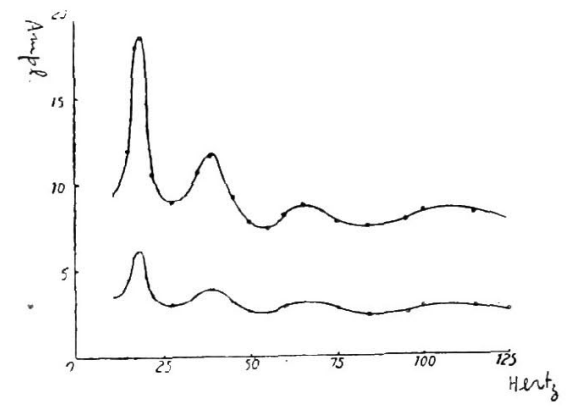

(b)

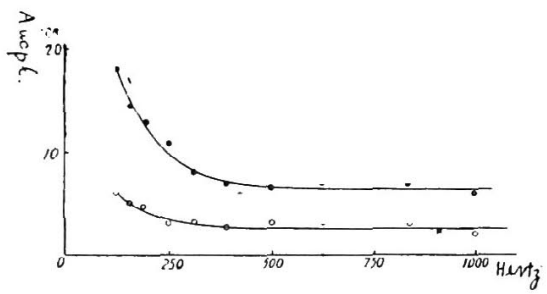

振㲜.上方ノ曲線ハ之二件フ地笼計ノ振動キ示入。 第 15 圖 第 14 圖ノ雨振幅ノ比キ取ッタモノ郎チ
第 15 圆

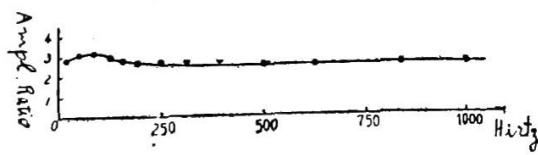

地震計ノ特性曲線デアル。之キ覞察セバ $100 \mathrm{Hertz}$ 以上デハ振幅比殆ンド一定シ居ルキ以テ(第 4) 酒 ベタ理論ニ依リ。特性曲線》諸點キ連ホタ所ノ横

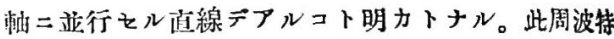

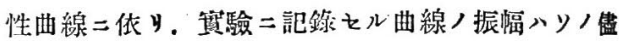
大キサキ比较スル事可能ナルキ證明サレiタノデフ ル。

仯木第 13 圖（a）八振動板 $\mathrm{P} /$ 自己振秒曲線打粲 二依ツテ取ツタモうデアル。對数減衰藮ハコノ曲線 ヨリ計算ノ結果: 0.08 。又第 16 圖川同様二地震計

, 自己振動曲線 第 16 圆 デ. 固有振動稘八

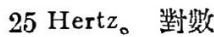
隇衰率入0.111。 故二 (2)式八 $\ddot{\theta}+$ $11.1 \dot{\theta}+24674 \theta=$ $-0.205 \ddot{x}$ 卜 ル。體壁ノ發馨二 伴フ共振ハ此固有 振動数ヨリ滛力二 大ナル振動数㔹 スルカタ減衰率、 サシテ重要デハナ 1 。

\section{第 四章＼cjkstart發警二伴フ體壁共振ニ關スル實驗成綪}

\section{第一節 Talkie Film 記錄}

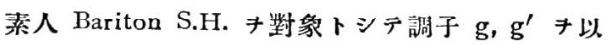
テ語音「ア」キ稍了强ク墢㢣セシメ，以下ノ場所二 於テ Pick up キ稍、輕ク觸レシメテ體壁ノ共振き 記錄七ル狀態八附圖第 1 圖乃至第 17 圖二示々ル如 シ.

圆二於テ時間ノ經過ハ左 $ヨ$ 右へ進行スル。縞模㨾 ノ濃淡入普通ノ畐波形ニ於々ル高低二相當シ。濃淡

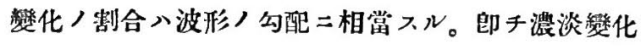

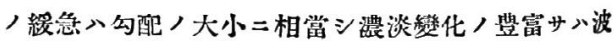
形ノ複雜サニ一致スル。濃淡ノ程度へ曲線ノ高低 程度ノ對稘キ示ス。上下ノ幅ニハ特別ノ意味ハナ 1 。

\section{苇一項 頸 胸 部}

(1) アダム隆起 Pomum Adami ノ部二テ(a)g(b) $\mathrm{g}^{\prime}$ ノ調子ニテ語音「ア」キ發㢣シッ、振動キ記錄 フ。g, $g^{\prime}$ 何レニテモ「ケ」，定型的圖形ニ於々N

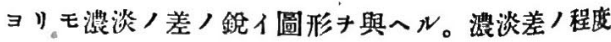




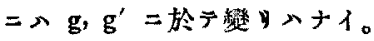

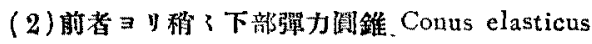

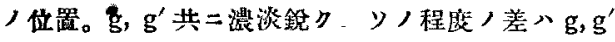
共二綎リハナイ。

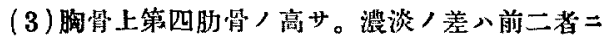

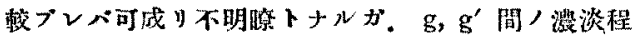
度ノ差哄バナイ。

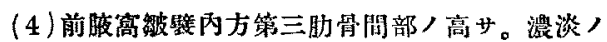

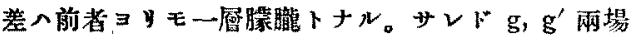
合, 程庭八同节。

(5) 肩眫骨問下部。g, g' 共二虽力二不明睹ナル

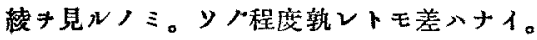

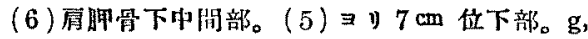
$\mathrm{g}^{\prime}$ 共二締ハ殆ンド見エナイ。

(7)右房胛骨中央部。g, $\mathrm{g}^{\prime}$ 共二無橉造。時二不 規則ナル繶入ルノミ。

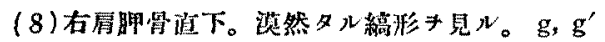
八其程度同

（9）左有盰骨㨁上。砝レド無㩐造。

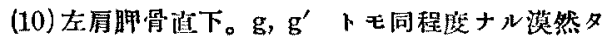

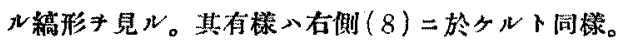

\section{䒜二垻 頭 部}

（11）前額中央部。 $g ， g^{\prime}$ 共二解明ナル縞模様

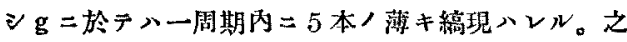
メ $\mathrm{b}^{\prime \prime}=960$ Hertz，第五倍音二相虽スルモノデ

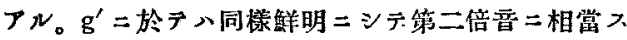
ル縞現ハレル。文 $\mathrm{g}^{\prime \prime}=768 \mathrm{Hertz}=$ 相當スル。

（12）前類右側部。g， $\mathrm{g}^{\prime}$ 同程度二鮮明。(11) 卜臵 マド晎ナラザル縞形デプル。

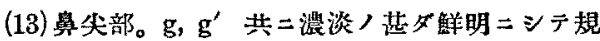

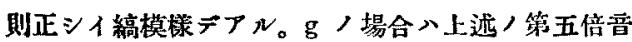

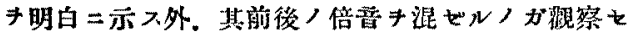
$\exists レ ル 。 g^{\prime}$ ，場合八第二倍音著明。

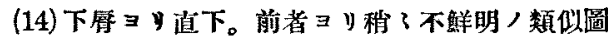
形丰示入。 $g, g^{\prime}$ 人場合，鲜明度二大差ナシ。

(15)右耳珠暗部。前顆中央部二於々ル埸合キ稍 ?

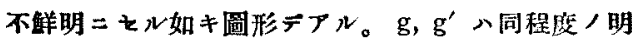

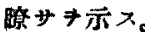

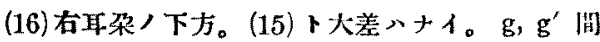
>明瞪度八同程崚。

(17) 項正中部。（11）類似ノ相當明暗ナル圖形キ示

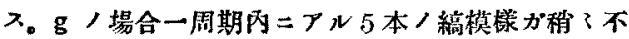

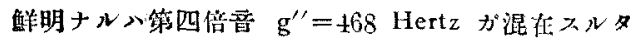

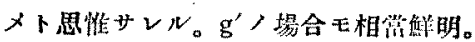

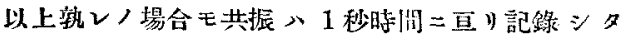
ガ. 其全䋑過二改ンデ圆形ハ殆ンド一様デフル故附 圆二ふ其一暗キ示七ルモノ ゙゚プ。

\section{第二節 地震計記淾}

菜人 Tenor S.N.。歌手 Tenor M.K. 矮樂女生 徒 Soparan H.U. 及 Mezzosopran Y.S. $/ 4$ 人斗對

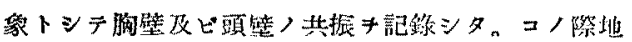

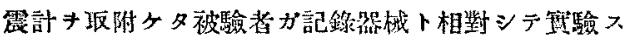

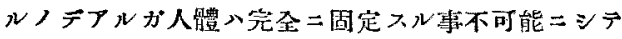

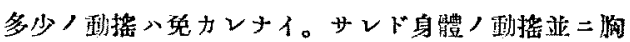

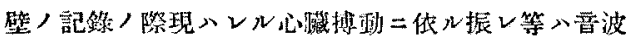

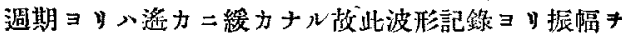
計算スルニ八少シモ差支へハナイ。而シテ多留人記

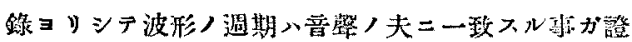

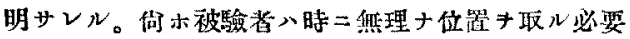
上. 光䫅杆ノ光芒八常二細ク经カラシムル牙小不可

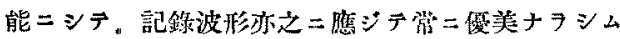

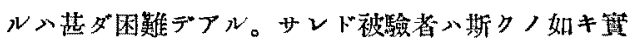

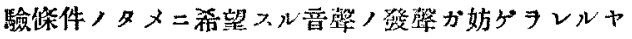

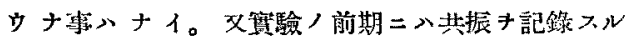

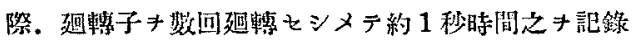
シタガ。斯クテ余時阙中波形二變化ナキキ知りタル

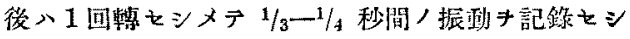
メテ測定シタ。何木本音デ振幅ト云フハ便宜上物理

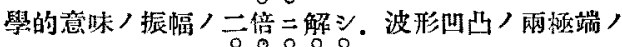

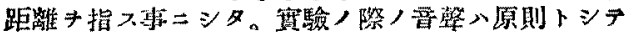
長三度筷二選ビ. S.N. 二於テハc-gis'間。M.K.

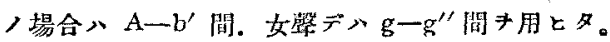
(附圆地震計記錄圆第 1 圖乃至第 32 圆參照。们尗附

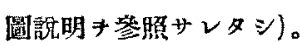

\section{第一項 8.N. ヨ對象トセル惯䮦 \\ 第一部 胸廍二於ヶル蚠酸}

(第一)。脢骨唡 Manubrium sterni 遖下。

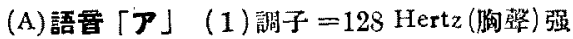
サ $\mathrm{mf}$ 。Film 波形，振幅 $0.1 \mathrm{~mm}$, 之キ前章 $(10)$ 式/理曲二依り 3000 デ除七バ絕對层幅キ得心。綛 對桭幅 $=3.3 \times 10^{-5} \mathrm{~mm}$. 程埌。

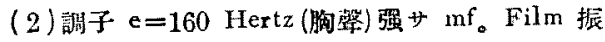
幅 0.1 . 絕對振幅 $3.3 \times 10^{-5} \mathrm{~mm}_{\text {。 }}$ 


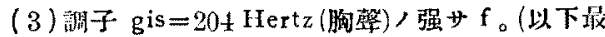

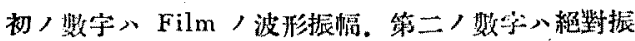
愊トフル。單位八 mm.)。0.2。6.7 $\times 10^{-5}$ (第 5 圆)。

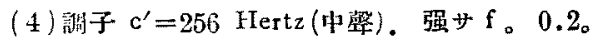
$6.7 \times 10^{-5}$ (第 5 圖)。

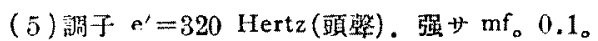
$3.3 \times 10^{-5}$ 。

(6) 謂于 gis' $=407 \mathrm{Hertz}$ (頭㢣)。强廿 $\mathrm{mf}_{0}$ 0.1。 $3.3 \times 10^{-5}$ 。

(B) 語吾 「1」。

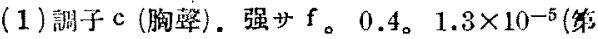
4 圆)。

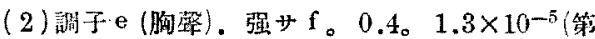
4 圆)。

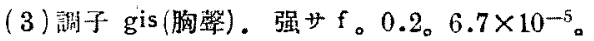

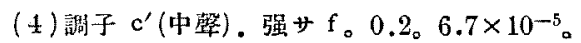

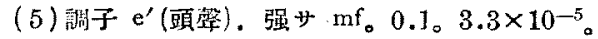

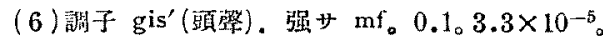

(C) 語望 [ウ」

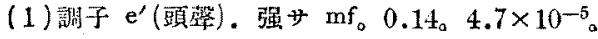

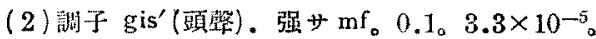

(D) 語琶「ン」

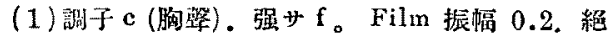
對振幅 $6.7 \times 10^{-5}$ 。

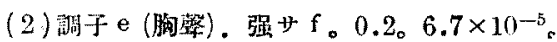

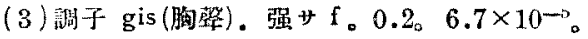

(4)偝子 $c^{\prime}$ (中㢣). 强サ $\mathrm{f} 。 0.2 。 6.7 \times 10^{-5}$ 。

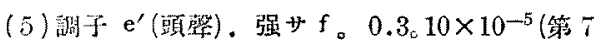
[圆]。

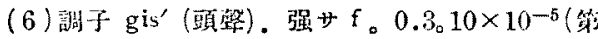
7 [圆)。

(第二)。右側乳房部(第四胁骨，高节)。

(A) 語要〔P」

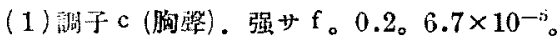

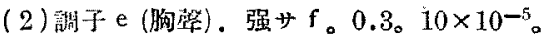

（3）調子 gis (胸馨)，强甘 $\mathrm{f} 。 0.3 。 10 \times 10^{-5}$ 。

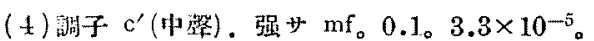

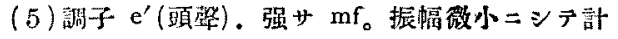
测不可能。

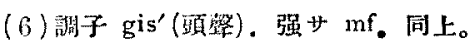

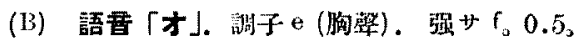
$17 \times 10^{-5}$ 。

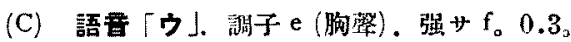

$10 \times 10^{-5}$ (第, 10 溷 a)。

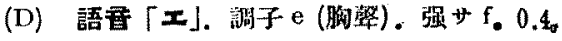
$13.3 \times 10^{-5}$ 。

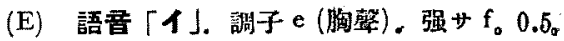
$17 \times 10^{-5}$

(F) 語整「山」

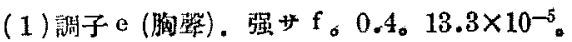

(2) 調子g (胸㢣). 强サ $f_{\circ} 0.2 。 6.7 \times 10^{-5}$ 。

(G) 語要「ン」.嗬子e。强サ $\mathrm{f}_{0} 0.3_{0} 10 \times 10^{-5}$ 。

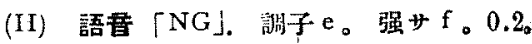

$6.7 \times 10^{-5}$.

(第三)。右，側胸部，(第五肋間挖/高节)。

(A) 語曾 $[\boldsymbol{P}\rfloor$

(1) 謨子 $\mathrm{c}$ 。强サ $\mathrm{mf}$ 。振幅微小。

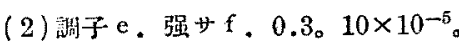

(3) 詿子 $\mathrm{e}^{\prime}$ 。强廿 $\mathrm{mf}$ ，振幅微小。

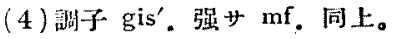

(B) 語镸「ウ」

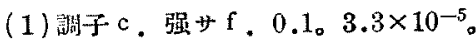

(2) 洲子 e, 强せ mf. 振幅微小。

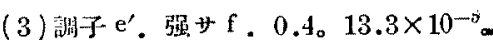

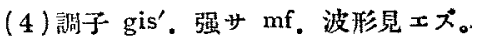

(第四)。左、㒋胸部

(A) 語香 $[\boldsymbol{P}\rfloor$

(1) 洲子 $\mathrm{e}$. 强出 $\mathrm{f} \quad 0.4 。 13.3 \times 10^{-5}$ (第 6 图)

(2) 䚴子 $\mathrm{e}^{\prime}$. 强サ mf. 波形見エズ。

(第五)。上腹部 (㧱狀突起直下)

(A) 語要「买

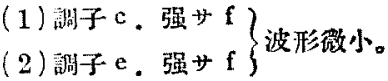

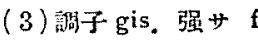

(4) 該子 $\mathrm{c}^{\prime}$. 强サ $\mathrm{mf}$

(5) 铜子 $\mathrm{e}^{\prime}$. 强せ $\left.\mathrm{mf}\right\}$ 波形兒 $x x^{*}$ 。

(6) 諳子 $\mathrm{gis}^{\prime}$.强廿 $\mathrm{mf}$ )

(B) 語雷「ウ」

(1) 誰子c。强出 $\mathrm{f}$

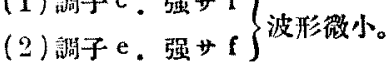

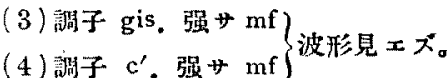

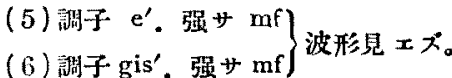

(第六)。局胛鼻間部上部。 


\section{(A) 語娄〔P」}

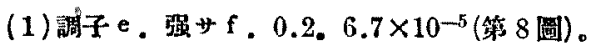

(2) 調子 $\mathrm{c}^{\prime}$ 。强廿 $\mathrm{mf}$. 振幅微小。

(3) 調子 $\mathrm{gis}^{\prime}$ 。强廿 $\mathrm{mf}, 0.1$ 。 $3.3 \times 10^{-5}$ (第 9 圖)。

(B) 語䡒「ウ」

(1) 調子 e. 强廿f，0.2。6.7 $\times 10^{-5}$ (第 8 圖)。

(2) 調子 $\mathrm{c}^{\prime}$. 强 $\mathrm{mf}$. 振幅微小。

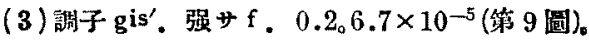

\section{(第t)。同胛骨間部中部。}

\section{(A) 語䡒「P $\rfloor$}

(1) 調子 e ，强サ f，振幅微小。

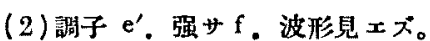

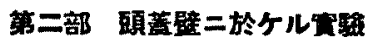

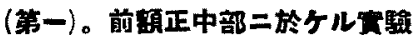

(A) 語番〔P]

(1) 搠子 c (胸慗). 强サ $\mathrm{mf}$ 。 Film 振幅 0.2 。 紹對振幅 $0.67 \times 10^{-4}$ 。備考。弱第二倍普現ハル。

(2) 調子 e (胸㢣). 强サ mf. 0.4 。 $1.3 \times 10^{-4}$ 。

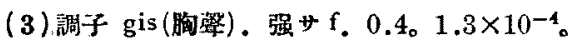

(4)調子 $c^{\prime}$ (中繁)。强少 f. $0.401 .3 \times 10^{-4}$ 。

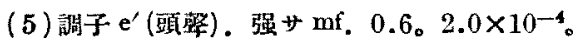

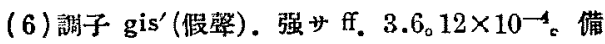

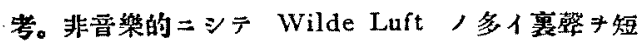
1間最强馨デ凨シタ埸合。

(B) 語書〔才」

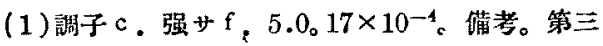
・倍昔现ハル(第 15 圖)。

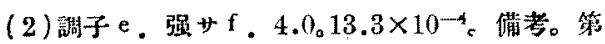
二倍晋ア》(第 15 圖)。

(3)調子 gis. 强出 . 3.5. $11.7 \times 10^{-4}$ 。借考。 第二倍豆アリ。

(4) 調子 $\mathrm{c}^{\prime}$ 。强》 $\mathrm{mf}, 0.6 \mathrm{o} 2 \times 10^{-4}$ 。

(5)調子 $\mathrm{e}^{\prime}$ 。强 $\mathrm{mf} .1 .0 \mathrm{o} 3.3 \times 10^{-1}$ (第 16 圖)。

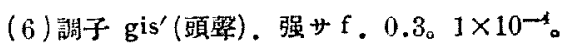

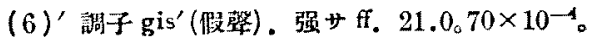

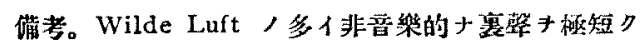
.f テ没㢣をル場合(第 16 圆)。

(C) 語書「ウ」

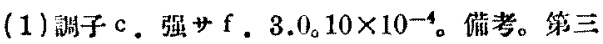
倍娄现ハN(第 12 圆)。

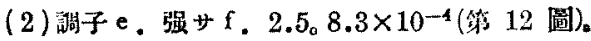

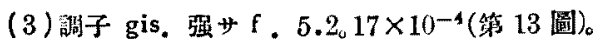

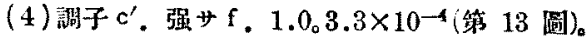

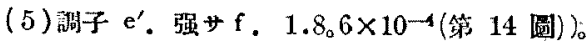

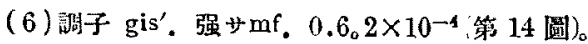

(D) 語書〔工玨

(1)調子 $\mathrm{c}$. 强严 $\mathrm{f}, 0.3 \circ 1 \times 10^{-4}$ 。

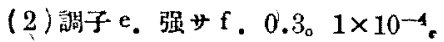

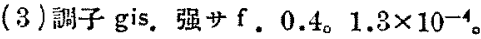

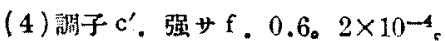

(E) 語要「イ」

（1）調子 c ，强中f， $3.5011 .7 \times 10^{-4}$ 。備考。第 二倍音現八心。

(2) 調子 $\mathrm{e}$ 。强类 $4.0013 .3 \times 10^{-4}$ 。備考。第

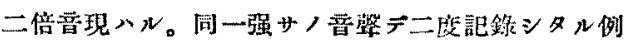
示入(第 11 圖)。

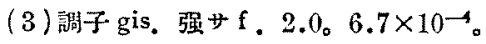

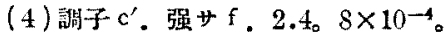

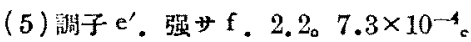

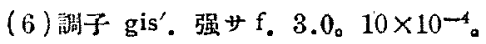

(F) 語番「ム」

(1) 湖子 c。强廿f， $3.2 。 10.7 \times 10^{-4}$ 。

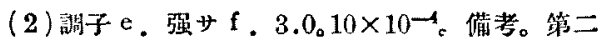
倍音出兴。

(3)調子 gis. 强革 $\mathrm{mf}, 0.802 .7 \times 10^{-4}$ 。

(4)調子 $\mathrm{c}^{\prime}$ 。强女 $\mathrm{mf} .1 .4_{\mathrm{o}} 4.7 \times 10^{-4}$ 。

（5）調子 $\mathrm{e}^{\prime}$. 强廿 $\mathrm{mf} .1 .5$ 。 $5 \times 10^{-4}$ (第 17 圆)。

(6)諳子 gis'。强 mf. $1.0 。 3.3 \times 10^{-4}$ (第 17 圆!。

(G) 語晋「ン」

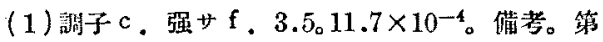
二倍音予y(第 18 圖)。

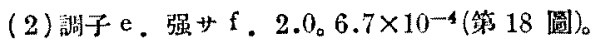

(3) 措子 gis. 强世 f. $2.4_{0} 8 \times 10^{-4}$ (第 10圆 b)

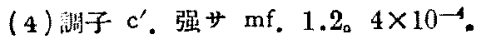

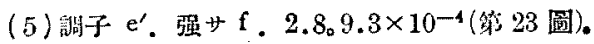

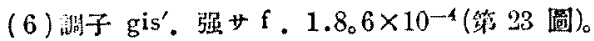

(H) 語晋 $\lceil\mathrm{NG}\rfloor$

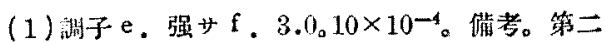
倍吾出米。

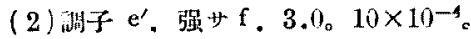

(I) 語尊 $\lceil\mathrm{L}\rfloor$

洲子 e。强せ $\mathrm{f}$. $3.00 .10 \times 10^{-4}$ 。

(J) 語尊「R」 
㒛子 e。强せ f， $1.0 \mathrm{o} 3.3 \times 10^{-4}$ 。

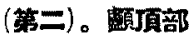

\section{(A) 語䡒 $[\boldsymbol{P}]$}

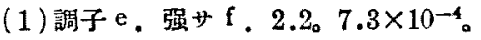

(2) 調子 $\mathrm{c}^{\prime}$, 强赤 $\mathrm{mf}, 0.4 \mathrm{o} 1.3 \times 10^{-4}$ 。

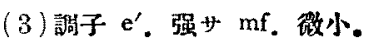

(B) 語要〔才」

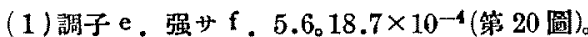

(C) 語畐「ウ」

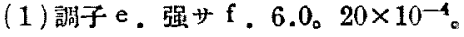

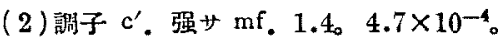

(D) 語要「工」

飘子 e。强出 $\mathrm{mf} .1 .6 \mathrm{o} 5.3 \times 10^{-4}$ 。

(E) 語䙵 $[1]$

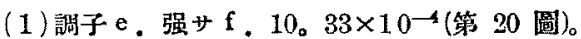

(2) 熘子 $\mathrm{e}^{\prime}$ 。强サ $\mathrm{f} \quad 0.401 .3 \times 10^{-1}$ (第 19 圆)。

(F) 語赖 [山]

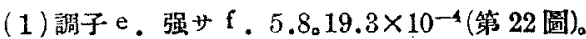

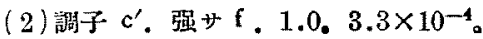

(3) 調子 $\mathrm{e}^{\prime}$ 。强サ $\mathrm{f} .0 .4_{0} 1.3 \times 10^{-4}$ (第 22 圖)。

(G) 語西 $[ン]$

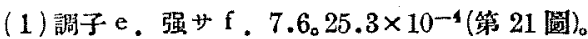

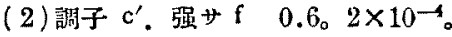

(3) 調子 $\mathrm{e}^{\prime}$. 强》f，0.4。 $1.3 \times 10^{-4}$ (第 21 圆)。

\section{(第三)。後頭部}

\section{(A) 語曋 $[\boldsymbol{P}\rfloor$}

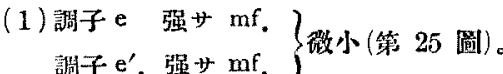

(B) 語善「ウ」

(1) 調子 e . 强サ f . 1.4。 $4.7 \times 10^{-4}$ (第 26 圆)。

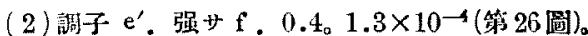

(C) 語富 $\lceil 1\rfloor$

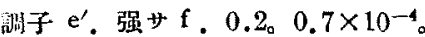

(D) 語覂 $「 ン 」$

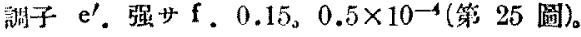

(第四)。右煩部

(A) 語畐「1」

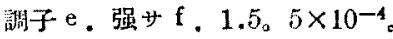

(B) 語琶「么」

調子 e 强开 $\mathrm{f} .1 .505 \times 10^{-1}$ (第 24 圆)。

(第五)。項部

(A) 語臬 $[\boldsymbol{P}\rfloor$
調子 e。强甘 $\mathrm{mf}$ ，微小。

(B) 語雷「ソ」

調子 e。强サ $\mathrm{mf}, 0.4$ 。 $1.3 \times 10^{-1}$ 。

(第六)。右僋頸部

(A) 語吾「P」

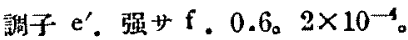

(B) 語专 [V]

(1)調子 e。强サ f，1.6。 $5.3 \times 10^{-4}$ 。

(2) 简子 $\mathrm{e}^{\prime}$. 强专 $\mathrm{f}, 0.3 \mathrm{a} 1 \times 10^{-4}$ a

(第七)。口底部

(A) 語音 $[\mathcal{P}\rfloor$

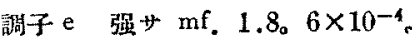

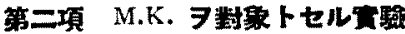

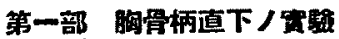

(A) 語曋「む」

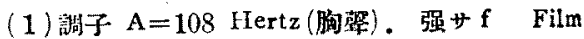
振幅. 1.2。絕維振幅 $40 \times 10^{-5}$ 。(第 29 图 a).

（2）讇子c (胸㢣)，强廿 f， $1 。 33 \times 10^{-5}$ 。

（3）調子 e (胸馨)。强サ f . $0.206 .7 \times 10^{-5}$ 。

(4) 简子 gis (中籍)。强》f .

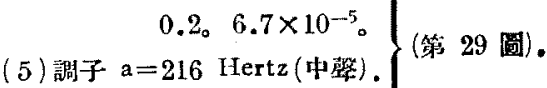

强甘 f. $0.2 。 6.7 \times 10^{-5}$ 。

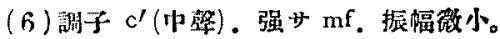

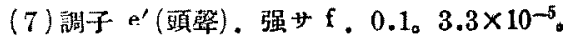

(8) 調子 $\mathrm{gis}^{\prime}$ (頭繁). 强廿 $\mathrm{mf}$. 振幅微小。

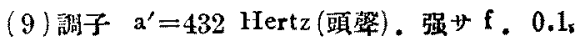
$3.3 \times 10^{-5}$ (第 29 圆 a)。

(B) 語曋「P

(1) 調子c．强せ $\mathrm{f} .0 .5017 \times 10^{-5}$ 。

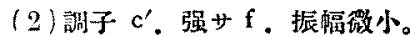

(C) 語要「ウ」

(1) 調子 c . 强サ f . $0.5 。 17 \times 10^{-5}$ 。

(2) 調子 $c^{\prime}$ 。强专 f 0.2 。6.7 $610^{-0}$ 。

(D) 語琶「エ」

(1) 䚴子 $\mathrm{c}$. 强サ $\mathrm{mf}, 0.7 。 3.3 \times 10^{-5}$ 。

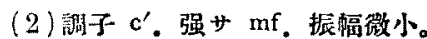

(E) 語陣 [1」

(1) 調子 c 。强正 f , $0.2_{\mathrm{o}} 6.7 \times 10^{-5}$ a

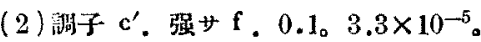

(F) 語䡒「人」

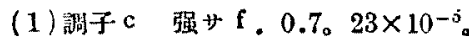


(2)調子 $\mathrm{c}^{\prime}$ ，强共 $\mathrm{f} ， 0.1 。 3.3 \times 10^{-5}$ 。

\section{第二部 前額中央部二於ケル目駼}

(A) 語券 〔イ」

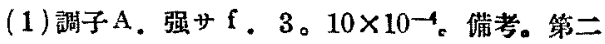
倍害アリ 第 1 圆)。

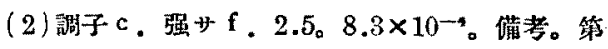
二倍晋子y（第 27 圆）。

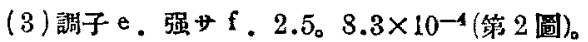

(4)調子 gis，强 f . $2.5,8.3 \times 10^{-1}$ (第 28 圖)。

(5)調子 $\mathrm{b}=229 \mathrm{Hertz}$. 强廿 ff. $3 。 10 \times 10^{-4}$ (第 3 圖)。

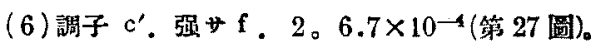

(7)調子 $\mathrm{e}^{\prime}$. 强サ $\mathrm{f} .1$ 。 $3.3 \times 10^{-4}$ (第 2 圆)。

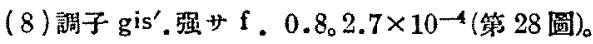

(9) 調子 $b^{\prime}=458$ Hertz. 强女f. 1 。 $3.3 \times 10^{-4}$ (第 3 圆)。

(9)'調子 $b^{\prime}$ 。强》 $\mathrm{mf} .0 .3 \mathrm{o} 1 \times 10^{-4}$ (第 3 圆)。

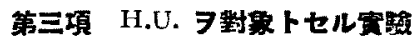

\section{第一部 眴骨唡正下}

\section{(A) 語吾「才」}

(1) 調子 $\mathrm{g}(192 \mathrm{Hertz})$ 。强サ $\mathrm{f} .0 .103 .3 \times 10^{-5}$ 。

(2)調子 h $\left(242\right.$ Hertz)。强廿f。 $0.103 .3 \times 10^{-5}$ 。

(3) 調子 es' $(304$ Hertz)

(4) 調子 $\mathrm{g}^{\prime}$ (384 Hertz)

(5)調子 $\mathrm{h}^{\prime}(483$ Hert $z)$ 波形現ハレズ。

(6) 調子 es" (609 Hertz)

(B) 語番「艿」

\section{第五草總}

\section{第一節 第四章第一節ノ總括}

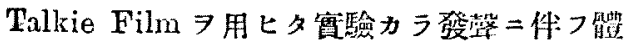
壁各部ノ共振，傾向 7 總括七バ次ノ結果二到達 ス。

1）胸部ニ於テモ，頭部二於テモ胸整 g及ビ

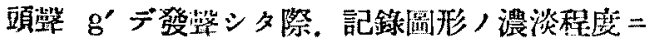

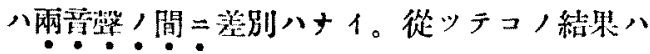

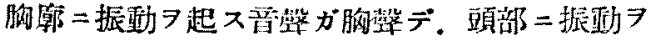

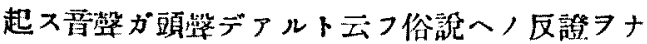

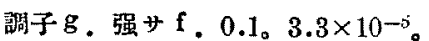

(C) 語要「么」

謂子 $\mathrm{g}$ 。强廿 $\mathrm{mf}$ ，微小。

\section{第二部 前額中央部}

䃁昔〔1」(第 30.31 圆)。

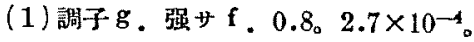

(2) 調子 $\mathrm{a}=215 \mathrm{Hlertz}$ 。强女 f. $0.5 \mathrm{o} 1.7 \times 10^{-4}$ 。

(3) 調子 h. 强 f $0.0 .301 \times 10^{-4}$ 。

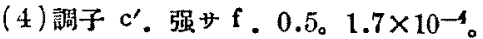

（5）調子 es'。强y f， 0.25 。 $0.83 \times 10^{-4}$ 。

(6)調子 $\mathrm{g}^{\prime}$. 强せ f，0.1。 $0.33 \times 10^{-\mathrm{s}}$ 。

(7) 調子 $\mathrm{c}^{\prime \prime}(512$ Hertz)

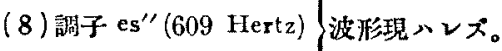

(9)調子 $\mathrm{g}^{\prime \prime}(768$ Hertz)

第四項 Y.S. ヨ對象トセル零理

第一部 周骨唡直下

語望「オ」

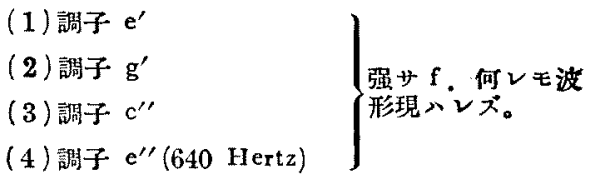

\section{第二部 前額中央部}

語音「イ」(第 32 圆)。

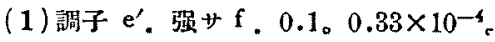

(2) 調子 $g^{\prime}$

(3)調子 $\left.\mathrm{c}^{\prime \prime}\right\}$ 强サ $\mathrm{f}$. 波形キ示廿ズ。

(4) 調子 $\mathrm{e}^{\prime \prime}$

括

x。

2）喉頭部／圖形八筀型的母音，夫レト八稍 ヤ異ナルガ强1漫淡ヨ示ス。喉頭內部，㱏波以

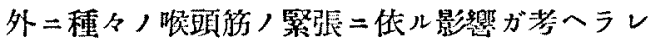
ル。

3）胸搱二於テハ胸壁前面デ振動强ク背部八 弱イ。振動二依ル濃淡率形八單純デアルカラ大 部分基畐ヨリ戊ル习裁ル。

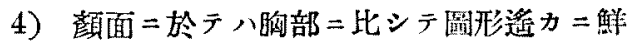


明. 複雜デ、或ル程度ノ倍音/混在ヨ認メル。 口裂二近キ篇メロヨリ出ヅル音波，影響八相需 考へ得ルガえヨ考慮ニ入レテモ湿淡，對照八胸

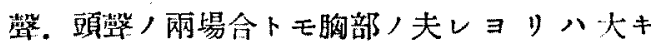
1 .

尚木注意スべキ八 Trendelenburg 7 始メ Mikrophon 7 用ヒ夕從本，如何ナル實驗デモ 蹧壁，共振 空氣ニヨリ直接 Mikrophenニ影響シナイトハ 斷ジ難1。然毛體壁，振動勢力八微小デアル故

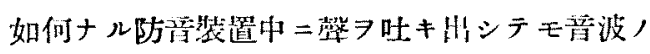
洩レノ影響八考へラレル。殊=健康ナル肺臓 共鳴域八主トシテ $135 \mathrm{Hertz}$ 前後故之ヨリ遙 カ二高イ振動數，倍音八體表へ傳播习妨ゲラレ

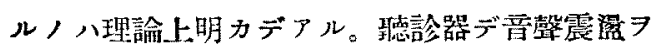

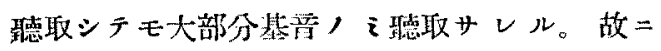
Talkie Film =依儿體壁振動，記鐵が少量乍ラ 吾嶅ノ影響フ受ケテキル事ハ考へ得ラレル。作

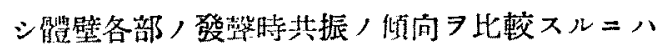
差支へナイ。地震計ラ以テ菑驗シタ結果八音紫 ，影響习全然除外出來ル。

\section{第二䇴 前章第二䇾第一項總括}

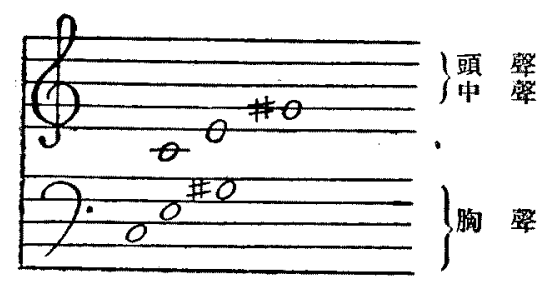

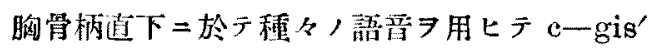
即于 128-408 Hertz 間, 三度音階, 各咅符=

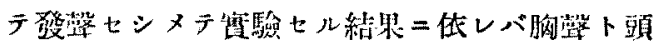
馨卜，間二於亏體壁共振，振幅美異八從來想像

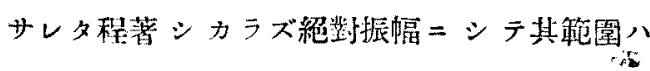

$3-13 \times 10^{-5} \mathrm{~nm}$. ，程度デアル(物理的 $=ハ 1.5$ $-6.5 \times 10-5 \mathrm{~mm}$.)。從ツテ頍韾，際二八胸部， 振動ハナ1ト云フ俗說ニ八全ク反スル結果デア ル。

胸影，他 部位二於ケル成績亦上还，結果 $=$ 矛 原セズ。

次二前額中央部 =於于各語音 $7 \mathrm{c}-\mathrm{gis}^{\prime}$ 間ノ三 度音階ノ各音符 果ニヨレバ胸韾，場合が概シテ共振々幅大デ頍 馨二行クニ從ツテ振幅へ減ズル事宽习㗀ル。振 幅，籍图八語吾「ア」エ」，場合习除ケパ大部 分 1.6-5 $\times 10^{-4} \mathrm{inm}$ 程度デアル (物理的=)。 又調子 $c, e$ 時二 gis 等デ，㭙二第二乃至第三

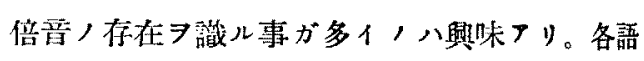

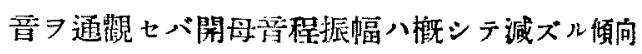
ア示ス。「ア」及「エ」，場合八振幅最モ小サ ク大船 $0.7 \times 10^{-4} \mathrm{~mm}$. 程度デアル。

頭壁二於テ八前额部. 胸壁二於テ八胸骨部方振 動最大故雨者八頭壁及ビ胸壁，代表卜看做シテ ヨイ。サレバ本均的二論ズレバ頭篮壁ノ振幅” 胸骨部ノ夫レ，10 倍近ク二達スル。但シ茲二 唯一ツ語湆「才」二於テ gis'，場合二例外 アリ。振幅 $35 \times 10^{-4}$ 二蓬スル。之八 Wilde

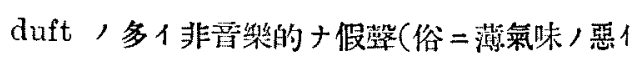

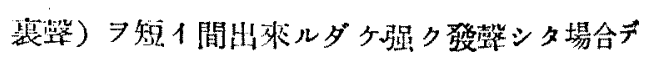
アル。他八場合. 就中歌手 M. K. 氏 場合= 八此如キ事ナク結检习破几程有力ト八思惟サv $+1 。$

碝頋部二於ケル共振が比較的大デアル，注目 二值スル。振幅入前額部ノ夫レヨ凌駕スル場合

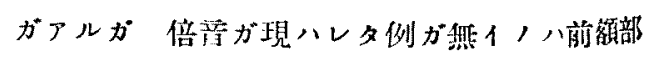
卜對照 $10 \times 10^{-4} \mathrm{~mm}=$ 達スルガ $\mathrm{e}^{\prime}, \mathrm{e}^{\prime}$ 二至ツテ急激 
二振幅が減ズル事筫八舅味アリ。換言スレバ頭 聲ニ至ツテ篦激二振幅が小トナル。調子 $\Theta^{\prime}$ デ 八平均 $0.65 \times 10^{-4} \mathrm{~mm}$. 程度デアル。

後頭部デハ概シテ共振が小サイガ站デモ前同滕 胸擎ヨリモ頭繁二至ツテ振幅が減ズル。

\section{第三蒒 前章第二蒒第二項總括}

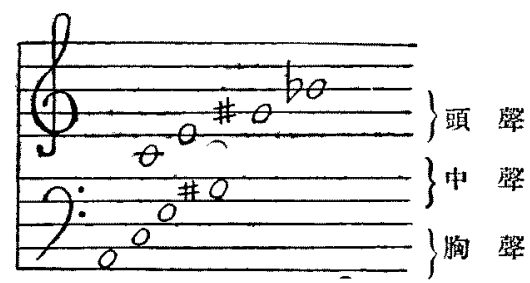

$A-w^{\prime}=108$ Hertz- 158 Hertz 間，三度隌階 ヨ用ヒテ前項同样，實驗 タ行ツタガ第一項ノ場 合ヨりモ振偪一般二大デアル，八專門整㲎家，

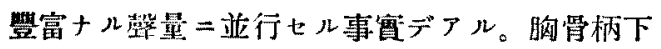
ニテ三度音階习胸整 $\mathrm{A} ヨ$ リ頭韾 $a^{\prime}=$ 至儿迄發 馨セシメテ實驗七ル結果二訨レバ此間振幅八規 則正シク變化シ (物理的振幅) $20 \times 10^{-5} \mathrm{~mm}$ 留 リ $1.7 \times 10^{-5} \mathrm{~nm}$ 迄減ズル(c一政間デハ $17 \times$ $10^{-5} \mathrm{~mm}$. $\exists$ リ $1.7 \times 10^{-5} \mathrm{~mm}$.)。高偣樂的頭 整二及ンデモ胸壁，共振が粗賞存在スル現象八 注目スベキデアル（語音「オ」，時胸壁人振幅 最大)。

次二前額中央部二於ヶル實驗二低レパ眴禁 $A \exists$ リ頭㢣 $b^{\prime}$ 二至ル迄振幅 八規則正シク變化シ $5 \times 10^{-4} \mathrm{~mm} . \exists リ 1.5 \times 10^{-4} \mathrm{~mm}$. 迄減ズル(c-

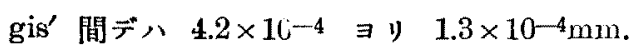
汽)。郎于頭蓋壁，共振二於テモ胸警，場合が 振幅遙カニ大デアル（語音「イ」，場合頭壁， 振幅最大)。

今同一八調子，發渻ニ伴フ前額及ビ胸壁二於ケ ル最大共振ノ振幅 $尹$ 比较スレパ（前額デ八語音
「イ」胸壁デ八語音「オ」，場合之二州常ス）。 潘㒭 調子 馨區 前額振幅 胸骨胍幅 比

(1) $\mathrm{A}) 5 \times 10^{-4} 20 \times 10^{-5} 2.5$

(2) $\mathrm{C}$ 胸 $4.2 \times 10^{-4} 16.7 \times 10^{-5} 2.5$

(3) $\mathrm{e}^{3} 4.2 \times 10^{-4} \quad 3.3 \times 10^{-5} 12.5$

(4) gis 7 中 $4.2 \times 10^{-4} 3.3 \times 10^{-5} \quad 12.5$

(5) $c^{\prime}$ 㢣 $3.3 \times 10^{-4} 1.67 \times 10^{-5}([1 」=$ ₹ $) 20$

(6) $\mathrm{e}^{\prime}$ 频 $1.67 \times 10^{-4} \quad 1.67 \times 10^{-5} \quad 10$

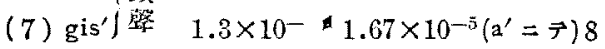

郎チ胸㢣上部及ビ中整二於テ兩者，比率最大 デアル。

\section{第四節 前章第二節第三，第四項總括}

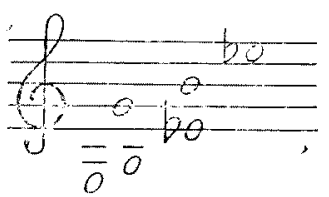

女㢣場合八男㢣 ，場合＝比シテ振幅 一般ニ小デアル。 H.U. $テ$ g一-2s"= $192 \mathrm{Hertz}$-609 Her'tz 問，三度㱏階上デ實驗 シタガ。胸骨柄下デ $\mathrm{g}, \mathrm{h}$ 等，調子デ $1.67 \times$ $10^{-5} \mathrm{~mm}$. ，小振幅現レタ，著シ1。 前額中央部二於テ，調子 $\mathrm{g}=$ 矤テ $1.3 \times 10^{-4} \mathrm{~mm}$ ，振幅习示シ調子 $g^{\prime}=$ 至儿迄㴬次減ジテ $g^{\prime \prime}$ 二於テハ $0.167 \times 10^{-4} \mathrm{~mm}$.二至ル。前額卜胸骨 柄下，振偪，比八調子gデ $8, \mathrm{~h}$ デ 3 。

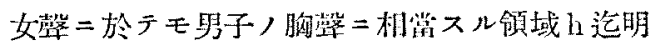

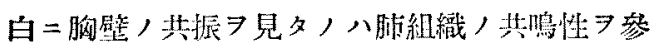
腎七バ與味がアル。

Y.S.，場合八皮下脂肪組織ガ侸カデ其狠八甚 ダ少ク、特二總括スベキ事項ハナ1。

\section{第五節 本章第二乃至第四節八綄說}

1) 触壁其振，週期八畐整，夫二一致ス几。

2）概シテ諭ズレバ，各場合卜モ胸樀及ビ頭

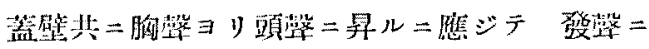
伴フ其振振幅入著減スル。即チ敦レ，部位 7 問

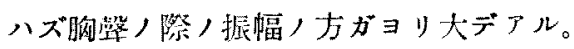


3 ）專門罄樂家，場合が其振振幅ヨリ大ナル

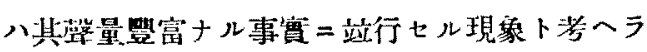
レル(男馨，場合)。

4）素人䠛樂家 S.N.，場合二比シ，專門馨 樂家 M.K. 及ビ㢣樂女生徒 H.U. /場合八發 馨ノ調子ガ暴ルト共二共振々幅ノ減ジ方が規則 正シイ

5) 胸壁。頍蓝臂共銳イ共鳴音域八見常ラナ

\section{第六草 考}

發馨二伴フ娟壁，振動ノ狀態八前述ノ如クナ ルガ. 前章第二箅 1)二述べタ如タ胸壁，共振 八打診音. 氣胞音ョリ得タ音ョリモ高1調子即 千 gis' 前後 (400 Hertz 前後) ニ於テモヨク 起ル事习識ツタ。之八胸部ノ振動八 90-400 Hertz デ最大デアルト諭ジタ Bass'(2)!，宦驗值 ニ一致スル。郎于遙カ二頚聲區，音韾二及ンデ

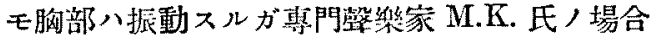
デ八 $\mathrm{A}$ - $\mathrm{a}(108-216 \mathrm{Hertz})$ 間デ共振最大デア ル。之八Giesswein ${ }^{(9)}$ ，場合二一致スル。好 触デ $\mathrm{h}(242 \mathrm{Hertz})$ 以下デ胸壁，共振ガ存在ス ルカ胸壁，最大自己振動領域八男姓卜モ大淁 ナイノ八鼠味樑イ。コノ音域八 Martini ${ }^{(19)}=$ 依 レ゙バ肺ノ自己振動语域二略に一致スル。

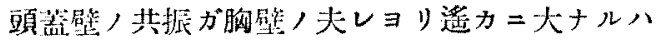
著シイ事デコノ際モ胸馨ノ場合ノ振幅がヨリ大 キ1。コノ事赛八既二 Trendeleuburg ${ }^{(30)}$ ，實 驗が示シタガ今回ハコ，事實 シー居具體的二登

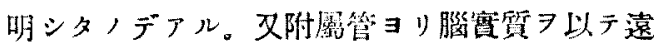
ク隔テラレタ㓺項部，其振が甚ダ大キ1，到 莣壁，音傳播性ト關聯シテ著シイ現象デアル。

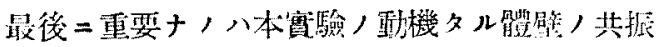

1。

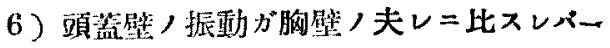
般二振幅. ヨリ大デ. 其比率八大部分 3-10倍 ノ程度デアル。

7) 大ナル振幅，例八胸壁デハ $2 \times 10^{-4} \mathrm{~mm}$. 頭盖壁デハ $1.7 \times 10^{-3} \mathrm{~mm}$. =達スル。敦レモ胸 槊場合デアル。

혼

トロ裂ヨリ出ヅル豆馨トノ關係デアル。

\section{第一蒒 㹂區卜）關保}

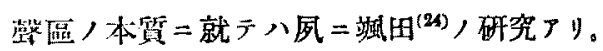
夫レニ依レバ胸馨及ビ頭学，依テ起ル相遠，原

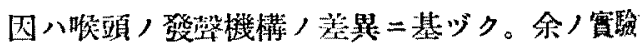
ハコノ結果ニ一致ス。何トナレバ胸韾．頭㢣共

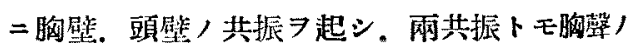
際ノ振幅ガ大デアル。然モ雨整區ノ移行部二於 テ共振振幅,變化ハ濑減的デアルカラデオル。 以上，理由二依り壁振動力゙雨馨區，音色／相遥 ノ本翼二何等關與シナイノ八自明デアル。

\section{第二第 晋掔勢力ト體壁共振ノ 勢カトノ關係}

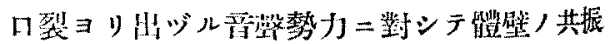
ガ若干ノ勢力ア供給スルヤ否ヤ、之二就テハ

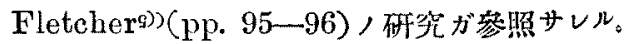

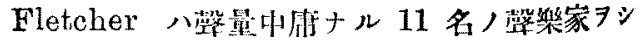
テ Wagner，『巡䄈，合唱』ラ唄ハシメ.コ

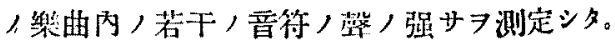
以下，裴八歌手 ヨリ 18 吋隔ッタ所デ Bar=

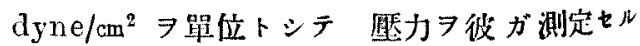
絬果デアル。 


\begin{tabular}{|c|c|c|c|c|c|c|}
\hline \multirow{2}{*}{ 繁種 } & \multirow{2}{*}{ pp. } & \multicolumn{2}{|c|}{ 力 (Bars) } & \multirow{2}{*}{$\begin{array}{l}\text { 䇨 } \\
\text { 力 }\end{array}$} & \multirow{2}{*}{ 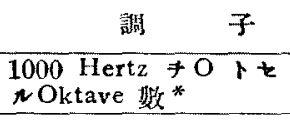 } & \multirow{2}{*}{$\frac{\text { 筑 }}{\text { Hertz }}=$ 換算 } \\
\hline & & mf. & ff. & & & \\
\hline Bass & 13 & 18 & 31 & \multirow{4}{*}{ 营 } & $-3.7--2.6$ & $77-165$ \\
\hline Tenor & 14 & 21 & 34 & & $-2.8--0.9$ & $144-536$ \\
\hline Soprano & 14 & 20 & 24 & & $-2.1-+0.2$ & $283-1149$ \\
\hline Alto & 6 & 13 & 18 & & $-2.5--0.2$ & $177-871$ \\
\hline
\end{tabular}

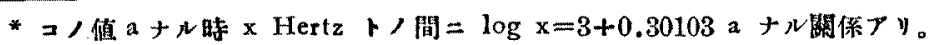

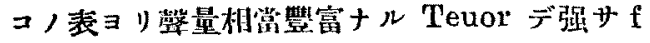
ナル警ノ壓力ハ少クモ 25 bars 前後ト見積ツ テ可ナルベシ。然ル＝ Fletcher =体レパ(同 眥 p. 67) 畐憵八近似的ニ牛球状ヨナシテロ

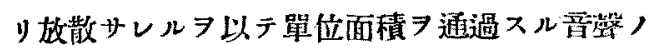
勢力ハ口ヨリ，距㗱，自乘二逝比例スル。作シ テ壓力 $\mathrm{p}$ ト勢力 $\mathrm{J} ト$ 間 $=ハ \mathrm{~J}=\frac{\mathrm{p}^{2}}{415}+ル$ 關係 アルラ以テ厴力ハロヨリ，距離=逆比例スル事 トナル。故二日裂，面樍が谌ダ小ナリト，假定

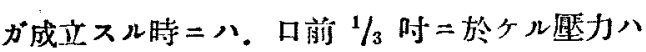
上表デ 25 bars，場会ニハ 1350 bars トナル。

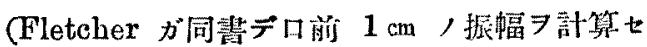
ル二倣フ)。

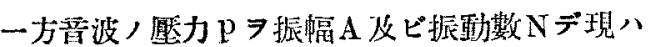
七准繁 p. 311).

$$
\mathrm{p}=41.5 \sqrt{2} \pi \mathrm{AN} \text { bars. }
$$

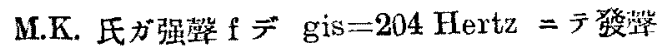

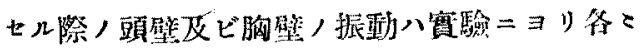

$$
\begin{aligned}
& A=4.2 \times 10^{-5} \mathrm{~cm}, \\
& A=3.3 \times 10^{-6} 6_{\mathrm{cm}} .
\end{aligned}
$$

之ヨ等を前式 $=$ 代入スレバ

$$
\begin{aligned}
& p=1.57 \text { bars .........(11), } \\
& p=0.124 \text { bars......(12). }
\end{aligned}
$$

即于口前 $1 / 3$ 时二於タル吾然，塺力か 1350

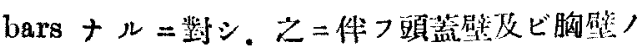

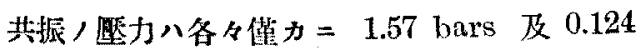

bars 二過ギナ1。

然モ頭蓋壁及ビ胸壁共二振動大ナル領域、比較

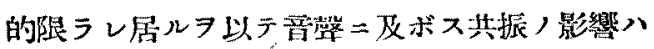
微小ナモノト諭ジテヨイ。

今コ, 關係ヨ一層詳細二砸究スルタメニロヨy 18 时 $=2.54 \times 18 \mathrm{~cm}$. ，距離デ 25 bars ナル登

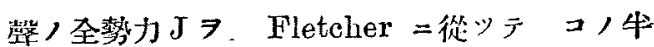

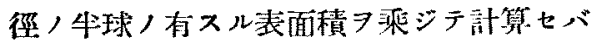

$$
\begin{aligned}
J & =\frac{p^{2}}{415} \cdot \frac{4 \pi^{\gamma 2}}{2} \\
& =\frac{25^{2} \times 2 \pi \times(2.54 \times 18)^{2}}{415} \\
& =19779 \text { Microwatts } \ldots . . . . . . .
\end{aligned}
$$

次=角額中央部，厘力 $\mathrm{p}=1.57$ bars ナル場合 ， $1 \mathrm{~cm}^{2}$ 二就テ，攀力 $J_{1}$ ，同栐，理的二低り

$$
J_{1}=\frac{1.57^{2}}{415}=\frac{5.94}{1000} \text { Microwatts......(14) }
$$

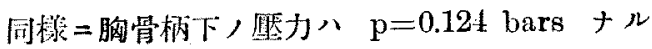
故 $1 \mathrm{~cm}^{2}$ 二就テ，繁力 $\mathrm{J}_{2}$ 从

$$
\mathrm{J}_{2}=\frac{0.124^{2}}{415}=\frac{3.71}{100000} \text { Microwatts } \cdots(15)
$$

双テ日本人娟表面積，测定二就テハ高比良氏

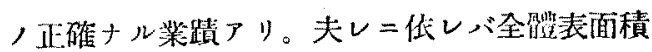

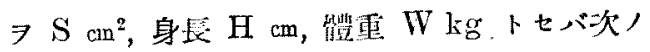
關係式が成市スル（平均謨养士0.95\%。聂大誤 涪 $\pm 2.64 \%$ )

$$
S=W^{0.425} \cdot 1^{0.725} \times 72.46
$$

M.K. 氏，埸命 $\mathrm{H}=165 \mathrm{~cm}, W=70 \mathrm{~kg}$ ナル故 
$\mathrm{S}=17862.5 \mathrm{~cm}^{2}$

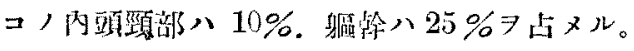
今頭政部，表面皘，牛分二及ンデ (11) 式デ示

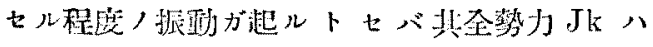
(14) $\vdash(16) \exists$ リ

$$
\mathrm{J}_{\mathrm{K}}=\frac{5.94}{1000} \times \frac{17862.5}{10 \times 2}=5.305 \text { Microwatts } \cdots(17)
$$

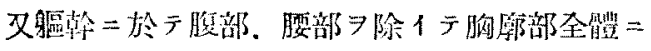
(12)式二示七ル程度/振動が赸ルトシ。そヨ最 大二見積ッテ軀筷, 全表面積, 牛分二達スルト 假定七バ．其全势力 $J_{\mathrm{B}}$ 八(15) ト (16) ヨり

$$
\mathrm{J}_{\mathrm{B}}=\frac{3.71}{100000} \times \frac{17862.5}{4 \times 2}=\frac{8.286}{100} \text { Microwatts...(18) }
$$

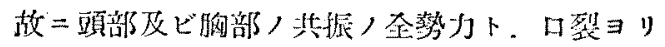
出ル音整，全勢力ト，比

$$
\begin{aligned}
& \text { (13), (17), (18) } \exists \text { v } \\
& \mathrm{K}=\frac{\mathrm{JK}_{\mathrm{K}}}{\mathrm{J}}=\frac{2.682}{10000} \fallingdotseq \frac{2.7}{10000} \\
& \mathrm{~B}=\frac{\mathrm{JB}_{\mathrm{B}}}{\mathrm{J}}=\frac{4.189}{1000000} \fallingdotseq \frac{4.2}{1000000} .
\end{aligned}
$$

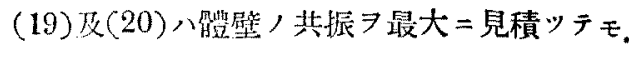

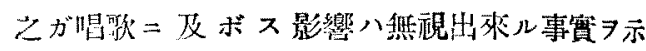

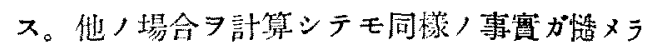
レルハ明カデアル。双繁二於テ八其层八遙力 ニ微小ナルフ第4 章ョリ誡レルタ以テ其振，全 等力八一層微弱ナルハ明白デアル。

\section{第三節 體壁ノ共振卜微小趙 勢力トノ關係}

以上，翼驗成績八主トシテ歌聲》用七タ場合

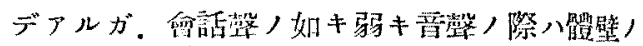
共振八遥力二弱ク其錐園乇狄1。之八余自身筧 驗ノ㝍デニ䚋察シ得タ所デアリ Sterni ${ }^{(26)}$ 亦 注意シテ居ル所デアル。

将レド今迄二觀察シ來ツ夕體壁共振ノ一例卜會

\begin{tabular}{|c|c|c|c|}
\hline 種 & 類 & 平均贸力 & 偖 \\
\hline 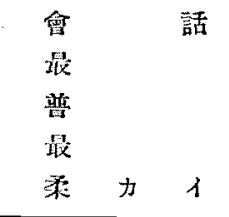 & $\begin{array}{r}\text { 譬 } \\
\text { 强 } \\
\text { 通 } \\
\text { 妈弱 } \\
\text { 咡語 }\end{array}$ & $\begin{array}{c}\text { (Microwatts) } \\
1000 \\
10 \\
0.1 \\
0.001\end{array}$ & $\left\{\begin{array}{l}\text { 口裂 } \Xi \text { y } 1 \mathrm{~cm} \text { デ振輻 } 1 / 100 \mathrm{~mm} . \\
\text { 口裂 } \Xi 10 \mathrm{~cm} \text { テ } 1 / 1000 \mathrm{~mm}, 2 \text { bars. }\end{array}\right.$ \\
\hline $\begin{array}{l}\text { 最 小 可 } \\
128 \text { Iertz } \\
200 \text { Hertz }{ }^{(11)} \\
256 \text { Hertz }\end{array}$ & 窗 & $\begin{array}{l}1.06 \times 10^{-6} \\
0.12 \times 10^{-6} \\
0.036 \times 10^{-6}\end{array}$ & $0.021^{\circ}$ bars \\
\hline $\begin{array}{l}\text { 蹬 } \\
J_{1}(204 \text { Hertz) } \\
J_{2}(\geqslant) \\
J_{K} \\
J_{B}\end{array}$ & 斯 振 & $\begin{array}{l}0.00594 \\
0.0000371 \\
5.3 \\
0.083\end{array}$ & $\begin{array}{l}\left\{\begin{array}{l}4.2 \times 10^{-1} \mathrm{~nm} . \text { Amp. } \\
1.57 \text { bars }\end{array}\right. \\
\left\{\begin{array}{l}\text { 振幅 } 3.3 \times 10^{-5} \mathrm{~mm} . \\
0.124 \text { bars }\end{array}\right.\end{array}$ \\
\hline
\end{tabular}
話整，平均勢力。其他，咅二關スル小勢力ト 列舅スルト以下，如クナル。但會話裂，本均勢 カニ八子焙及ビ休止時間 (Fletcher p. 68, p. 140)。

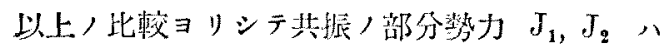

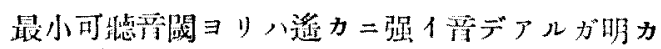

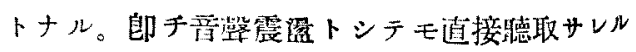
理デアル。殊 $=J_{1}$ 八四語/樊力八約 6 倍+ル 
八注目 $=$ 值スル。又胸壁共振，全勢力 $J_{B}$ 八最

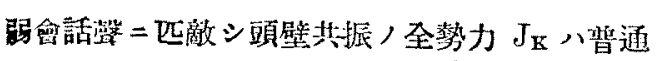

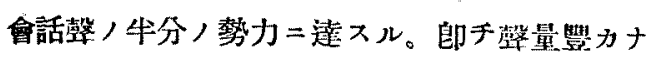
歌手方唱歌，際二體壁，共掋二費不劫力八侮り

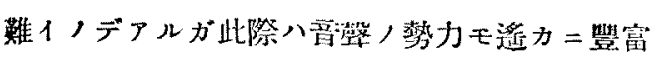
ナル故前者，音場二及ボス影怨八微小デ第二諓

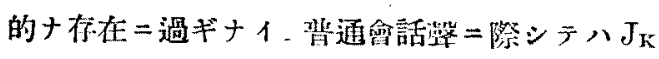

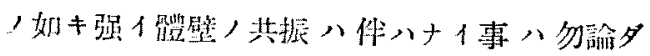

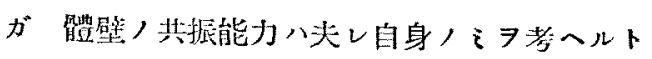
相常注日サルベキ現像デアル。サレド厚着，服

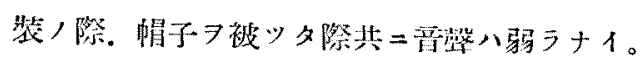

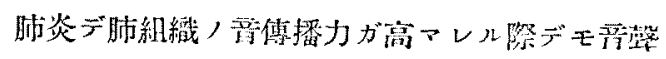
八强マラナ1。瑟由八上述，通りデアル。

\section{第七草總結論}

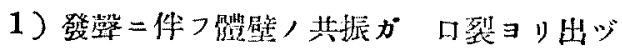

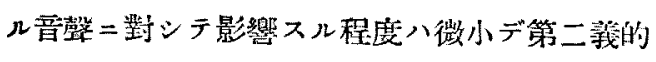
ニ過ギナイ。

2) 此共振八馨區，本質二八關係ナ1。

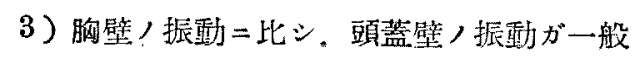
二振幅大デアル。

4 ）體壁ノ共振二八鈆供鸣音域八存在シナ 1。敦レノ場所デモ概シテ低嚾ハ振幅が大キ 1.

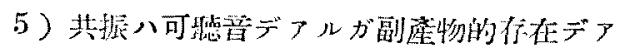
ルカラ 體壁八異, 意味, 勇放散盤 Schallabstrabler デハナイ。

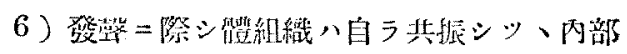
ヨリ娟表面迄其振動 㑑播スルノデアルカラ此 现像ニヨリ然ラザレバ票整二振り向タラルベ

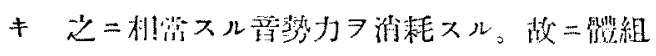
織八涪消耗者 Sehalldämpfer トシテ働ク。

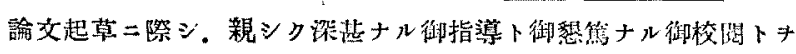

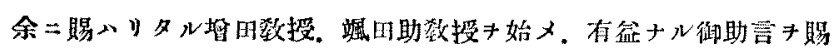

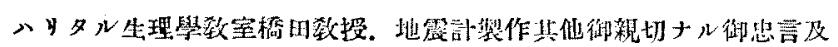

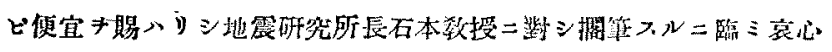

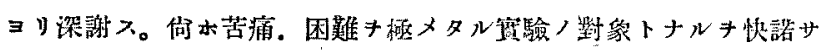

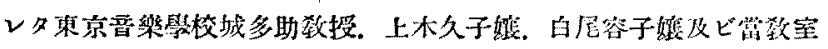

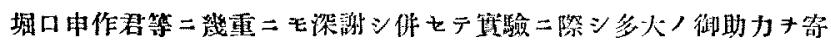

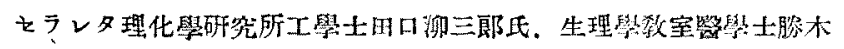

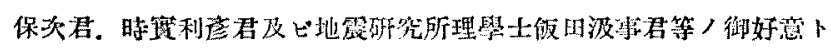

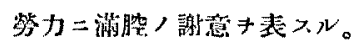

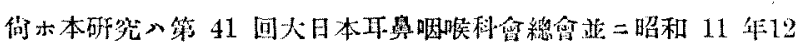

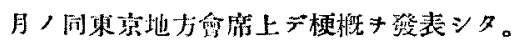


1) Bass, E.: Uber das Wesen der Atemgeräusch. Zschr. f. d. ges. Exp. Med. Bd. 59, S. 133, Bd. 63, S. 578, 1928. 2) Ders.: Das akustische Frequenzspektrum norm. u. infiltr. Lungengwb. Verh. d. Deutsch. Ges. f. inn. Med. Bd. 40, S. 166, 1928. 3) Cobet, R.: Untersuchng. u. d. Stimmfremitus, Deutsch. Arch. f. k1. Med. Bd. 155, S. 199, 1927.

4) Edens, E.: Lehrbuch d. Perkussion u. Auskultation S. 158, 1920. 5) Fletcher, M.: Speech and Hearing, p. 67-68, 96-97, 140, 308311, 1929. 6) Forehhammer, J.: Was ist. Resonanz, u. welche Rolle spielt sie bei der Stimmbildung? Die Stimme XXVIII-Jg. Heft 12, 1934. 7) Frey, H. = Experimentelle Studien u. d. Schalleitung im Schädel. Zschr. f. Psychol. u. Physiol. d. Sinnesorg. Bd. 28, 1902. Weitere Untersuchg. u. die Scballeitg. im Schādel, ebenda Bd. 33, 1903. 8) Giesswein, M.: Über die „Resonanz“ d. Mundhōhle u. d. Nasenräume, im bes. d. Nebenhöhlen d. Nase. Beitrāge z. Anat. usw. d. O-N-H. Bd. 4, S. 317 , 1911. 9) Ders.: Die Resonanzbeziehung. $z$ w. Stimme w. Brustorganen. ebenda Bd. 22, 1925. 10)Gritzmer: Physiol. d. St. u. Spr. in Her* mann's Handbuch. d. Physiol. 1879. 11) 橋田邦

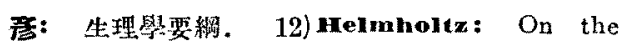
sensations of tone. Trans. by A. J. Ellis, p. 98, 1912. 13) Hennig, c. R.. Über die Entstehung der hohen Resonanz, Leipzig 1902. 14) Mnsson u. Tarmeaud: Rev. de Laryngologie etc. T. 53,1932 . 15)石本已四雄: 振㳩

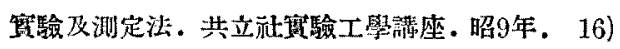
Iwanof: Zschr. f. Psychol, a. Physiol. d. Sinnesorg. Bd. 33, 1902. 17) Katzensteim, J.:
Über Brust., Mittel- u. Falsettstimme. Beiträge z. Anat. etc. d. Ohres etc. Bd. IV, S. 271, 1911. 17a) Katzensteim, J.: Methoden zur Erforschung der Tätigkeit des Kehlkopfes sowie der Stimme und Sprache. Handbuch der biologischen Arbeitsinethoden von E. Abderhalden S. 380, 1930. 18) Maljutin, E. N.: Die Bedeutung d. Form d. harten Haumens als eines wichtigen Bestandteils d. Resonators beim Singen. Arch, f. Isryngol. u. Rhinol. Bd. 9, S. 40, 1899. 19) Martimi, P.: Studien itber Perkussion u. Aus. kultation. Deutsch. Arch. f. kl. Med. Bd. 139, 1922. 20) 三扵网聂, 助川民之七：力學, 昭10年. 21) Molx, A.: Singen a. Sprechen (Reclam). 22) Rabotmof, 1. D.: Zur Frage über die Stimmbildung bei Sāngern. Zschr. f, Hals-usw. Bd. 2, S. 322 , 1922. 23) kayleigh: The thenry of sound. Art. 318, 1898. 24) 细田瑟次:

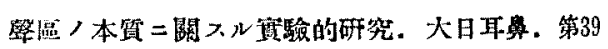
㭝, 2274頁，昭8年．25)罣崎定之：基磼唱歌法. 昭9年. 26) Stexn, M.: Gesangs-physiologie u. pãdagogik in ihr. Bezieh. z. Frage d. Muskelimpfd. u. d. beim Singen am Schâdel u. am Thorax fülbaren Vibrationen. Machr. f. O.L-R. Jg. 46, S. $337,1912.27)$ 由口娜三郎：發韾活

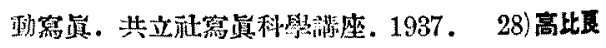

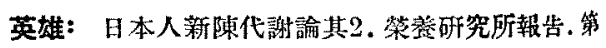
1卷，筹1號，61頁，大14年２9) Tondorf：Zur Physiologie d. menschl. Stimmorgans. Zschr. f. H-N.O. Bd. 22, S. 412, 1929 . 30) Trendelenburg, w.: Physiologische Untersuchungen über die Stimmklangbildung. Sitzgsb. d. preuss. Adad, d. Wiss. XXXI-II, 1935. 


\section{野 村 論 文 附 圖}

發馨二伴入體壁共搌, 保驗的研究

Talkie 記錄(第 $1-17$ 圖)

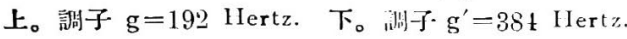

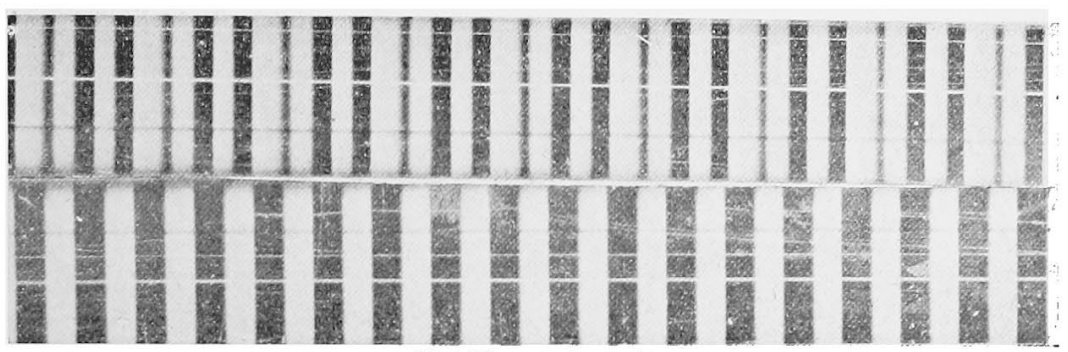

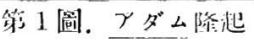

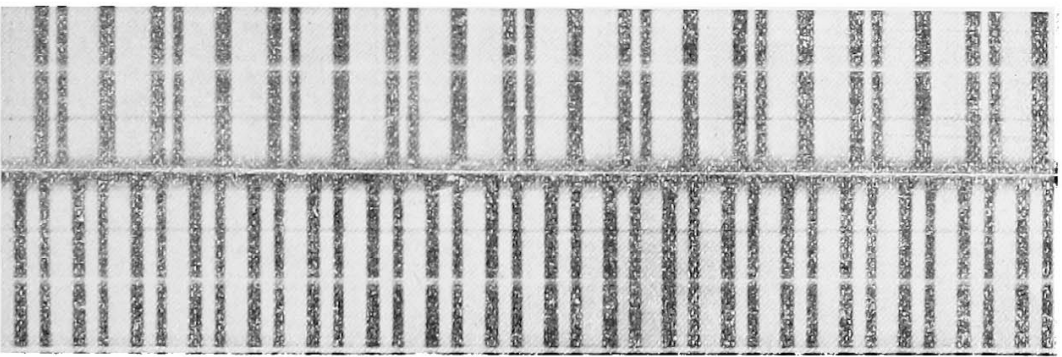

第２圖。紧力证錐部

(第 3 䀦省略)

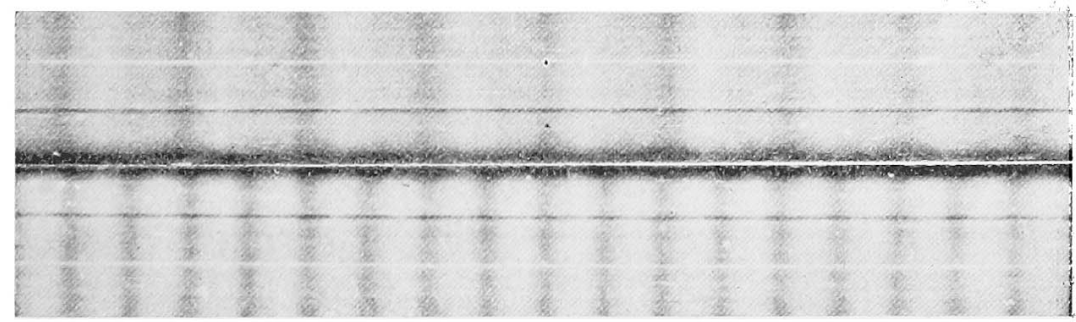

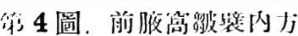

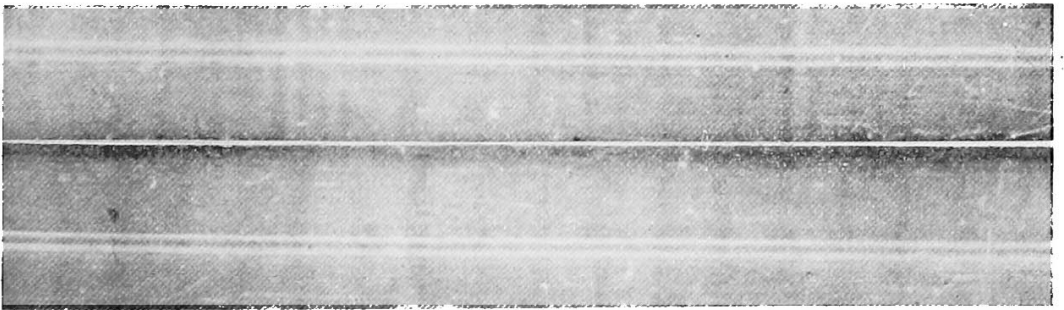

籍5 圆。居胛少滥下部

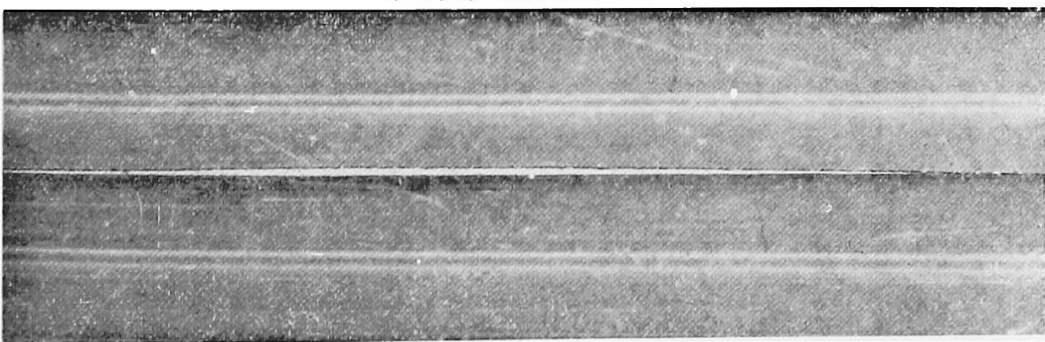

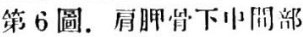

Dr. Shintaro Nomura: Fxperimentelle Studien über die Mischwingungen der Körperwand bei der Stimmbildung. 


\section{野 村 論 文 附 圖}

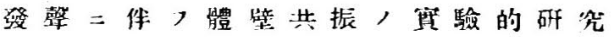

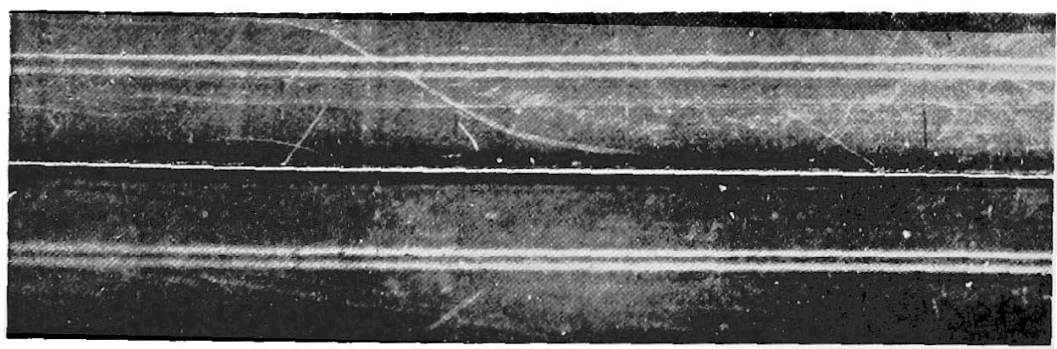

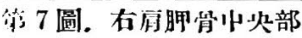

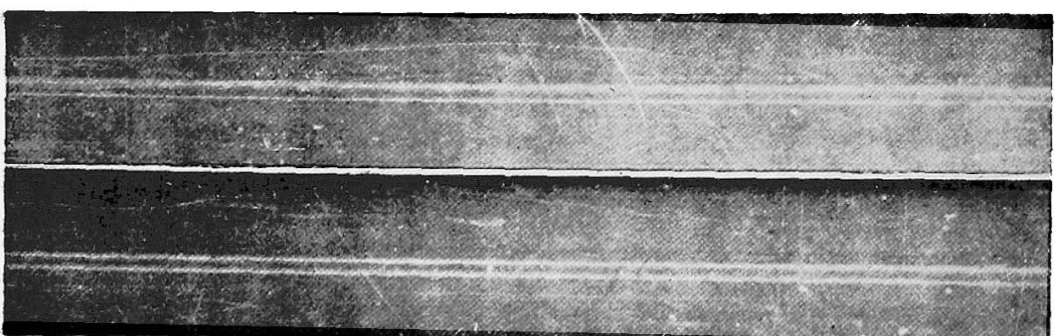

第 8 圖。右局胛筲官下

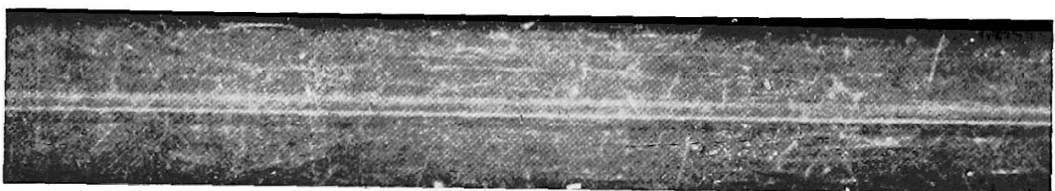

第 9 圖．左有盰骨㨁上

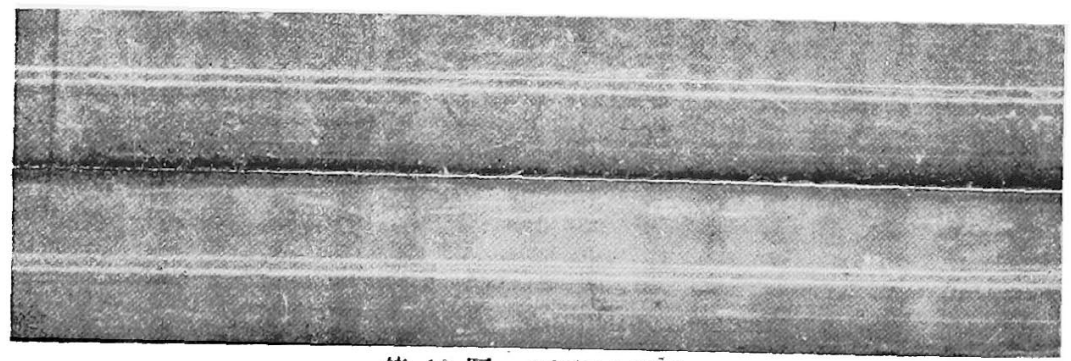

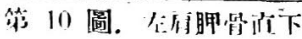

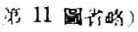

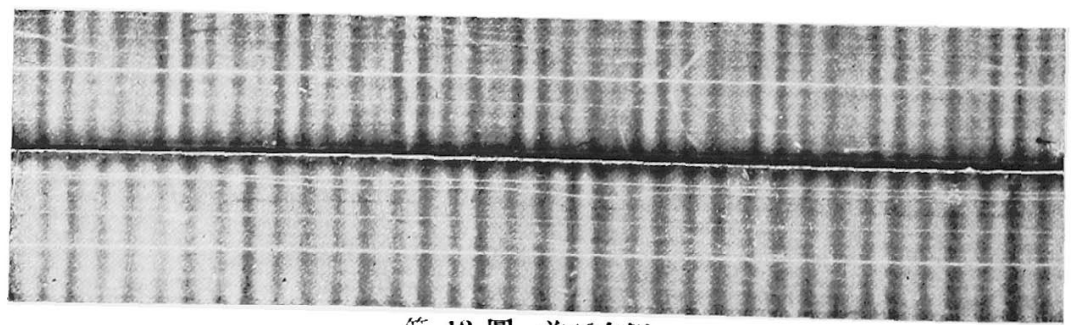

筷 12 圆。前㲅有侧

Dr. Shimtaro Nomnra: Experimentelle Studien über die Mitschwingungen der Körperwand hei der Stimgitdunge 
野 村 論 文 附 圖

發馨二作入體壁共振，貫驗的研究

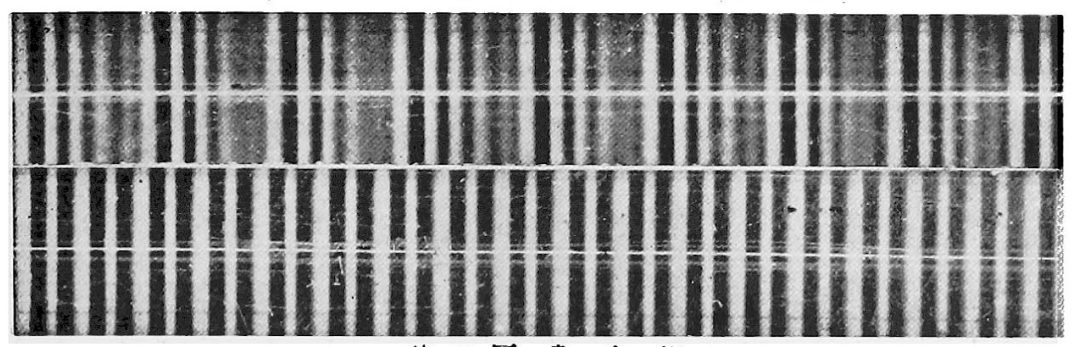

管 13 圖. 鼻 尖 部

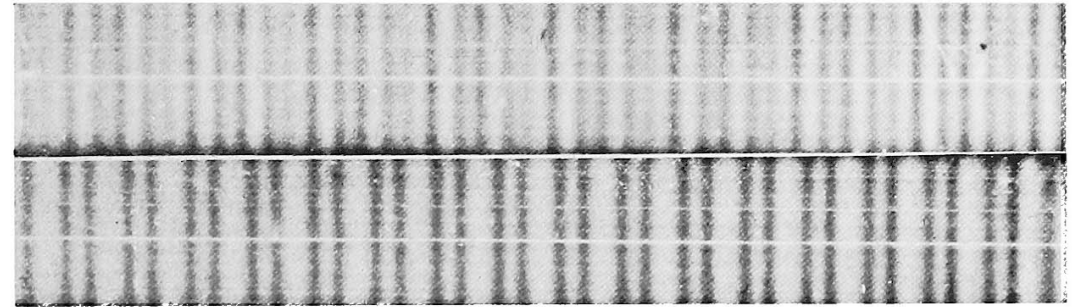

第 14 圖.下觕下部

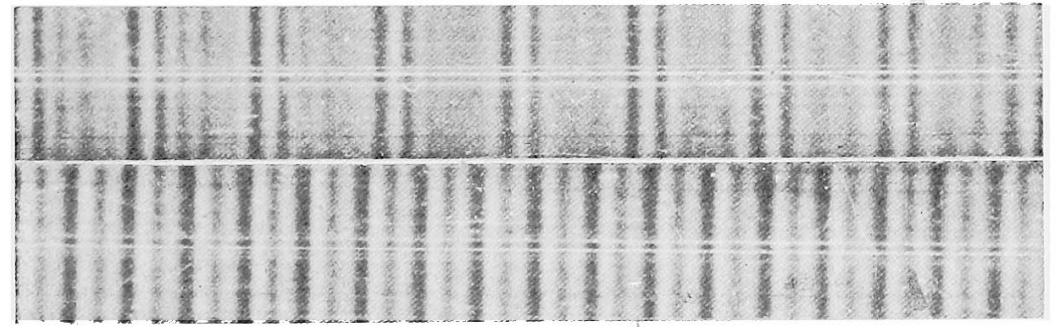

第 15 圖. 右耳珠前部

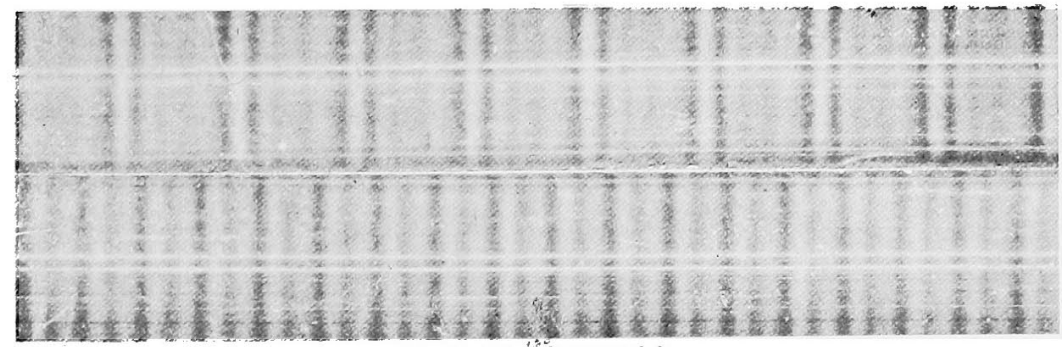
第 16 圆. 右耳梨下方

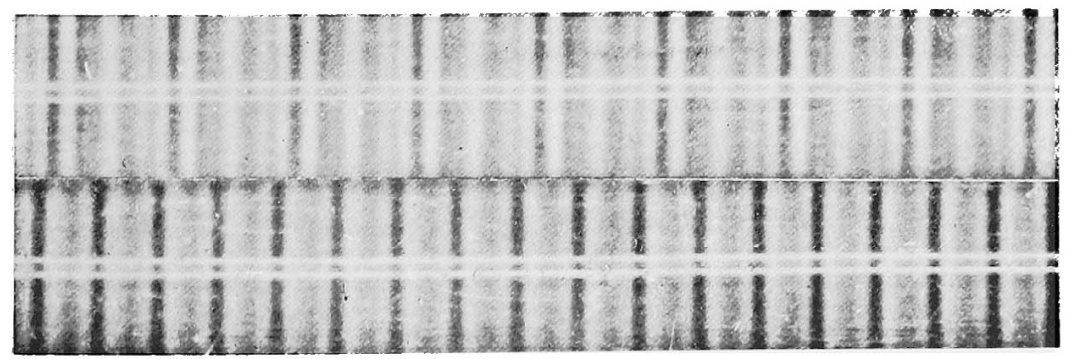

第 17 圖. 項部

Dr. Shimtaro Nomura: Experimentelle :Studien über die Mitschwingungen der Körperwand hei der Stimmbildung. 


\title{
野 村 論 文 附 圖
}

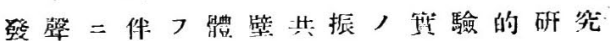

\author{
地 震 計 記 錄 圖
}

(筈; 1 - 33 圖)

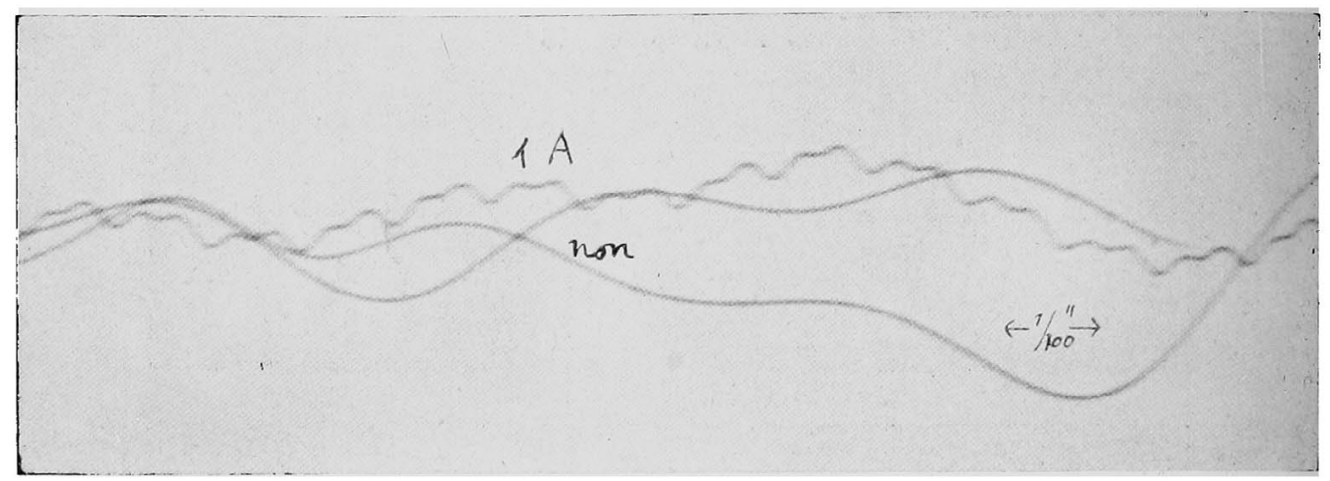

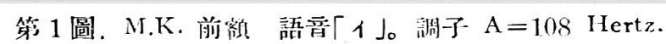

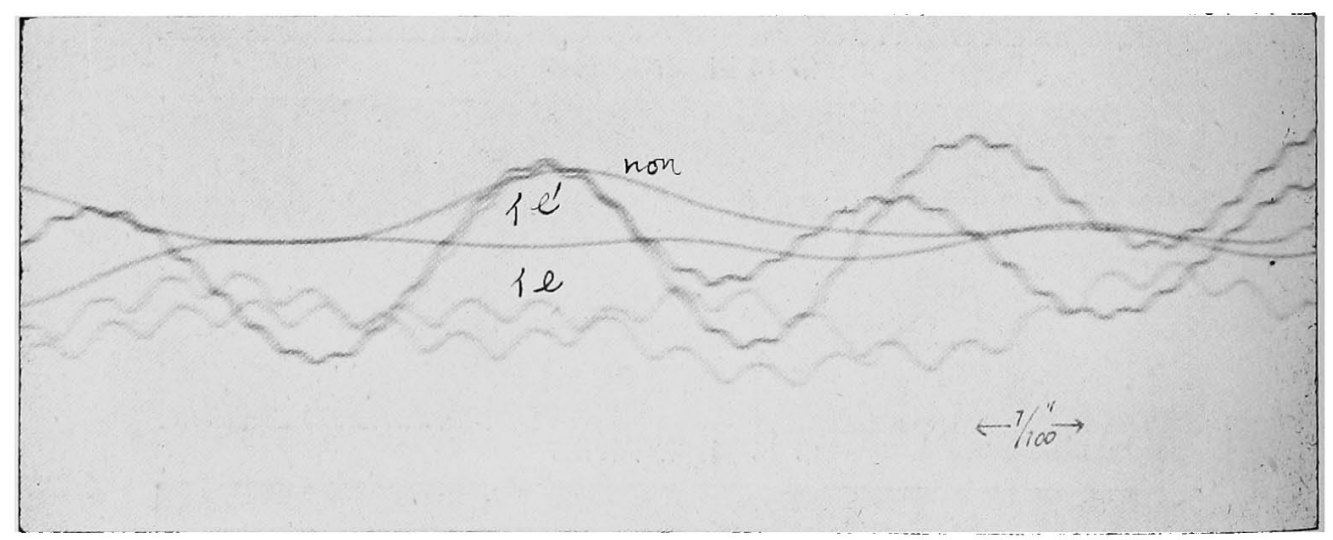

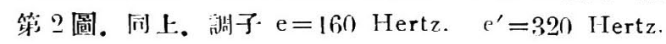

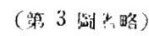




\section{野 村 論 文 附 圖}

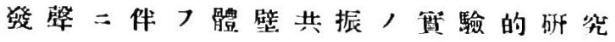

第 5 圆

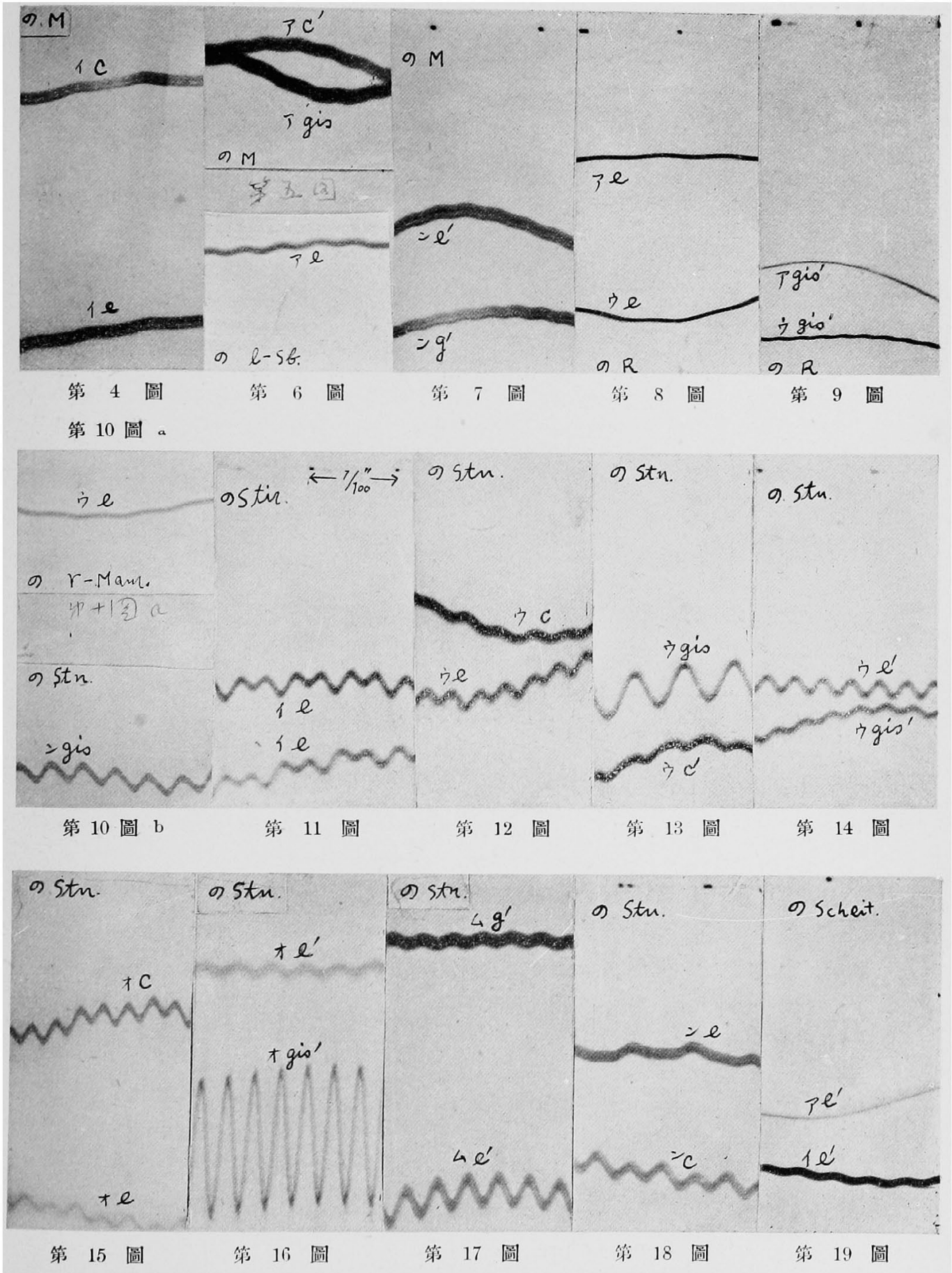

Mr. Shiuraro sommra: Experimentelle Studien über die Vitschwingungen der Körperwand lei der Stimmlildung. 


\section{野 村 論 文 附 圖}

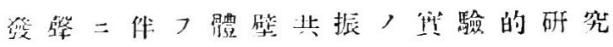

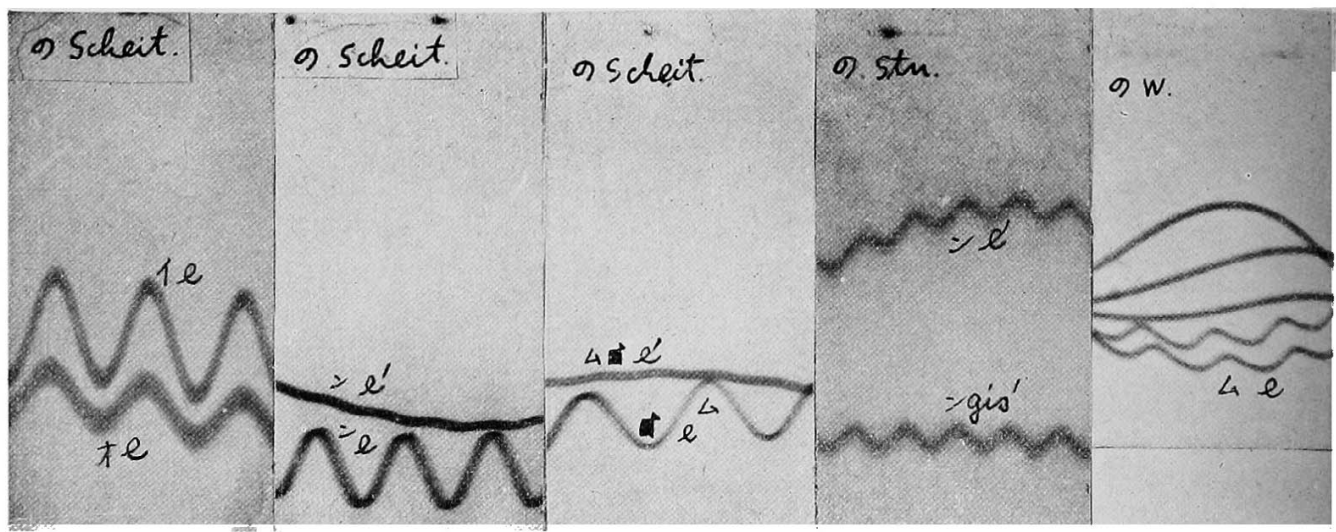
第，2）四
笵 21 圖
推; 22 圖

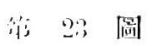
符 24 圖

節 29 圖

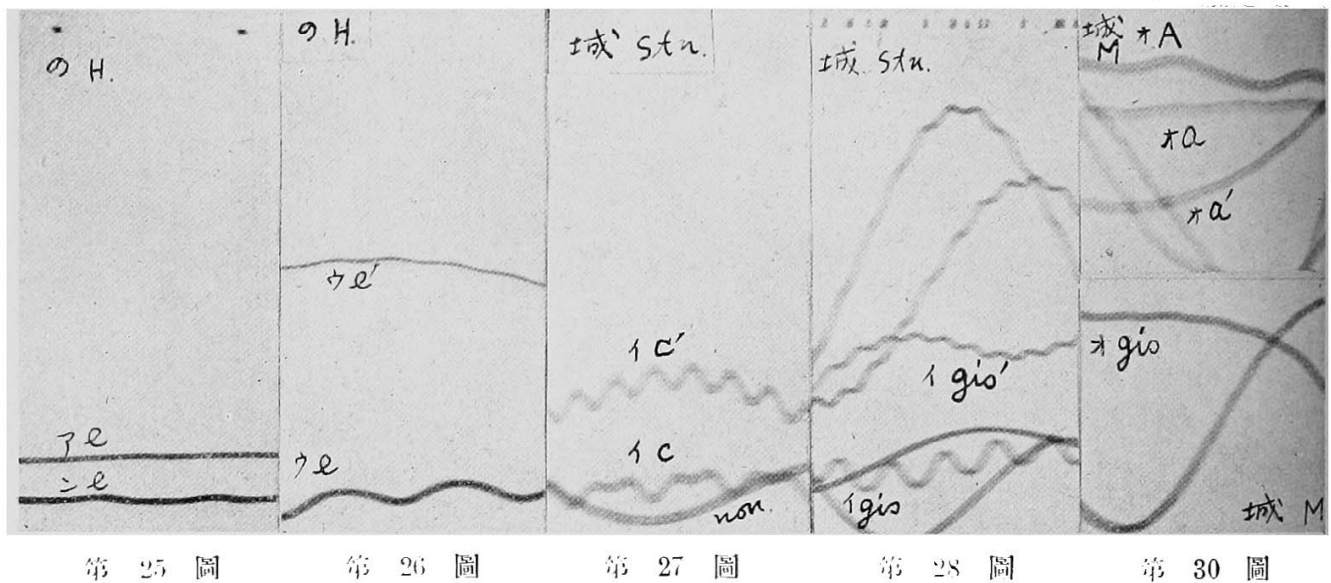

筆

彷２（；四

行 27 風

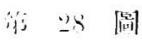

脯 30 圖

第 32 圆

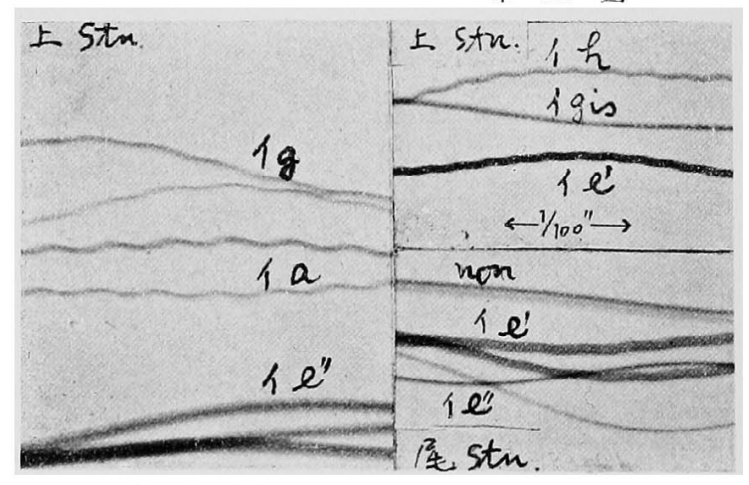

篗 31 圆符 29 圆 


\section{附 圆 铚 明}

Talkie 記錄圆第 $1-17$ 圆二於デ ハ本交第四章第

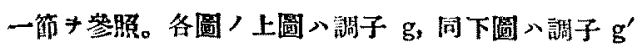
ニテ發㢣セル際ノ共振デアル。即チ前苗入胸㢣。後

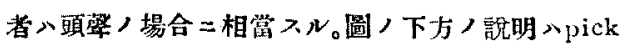
up キ常デル部位キ元ス。

地露計記䠌圆 (第 1 一第 32 回回)

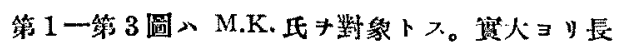
$\forall=$ 就テ $1 / 2$ 二縮小. 類似曲線ガ 2 佟以上アル入䢙 耧子キ1回以上迴轉シタル二依ル。曲線二於テ大ナ

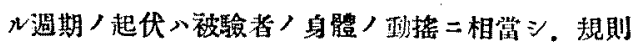
正シク絽返へメ小廵伏八體壁〉共振二相當入。此小

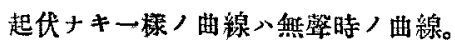

上流 シテッノ一造期、1/100 秒二相党フ。

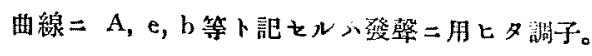
nonト羊七ルハ無㢣時ノ曲線。

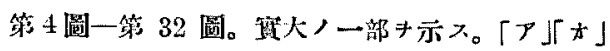

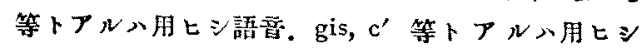

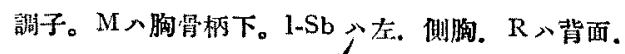
r-Mam. 八右礼原部。Stn. 久八Stir, 八前福中央。

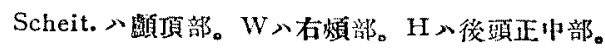
第 4一第 26 圆。S.N. *数象ト久。 第 27一第 30 圆。M.K. Ұ對舜卜久。

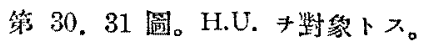

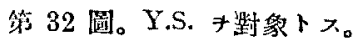

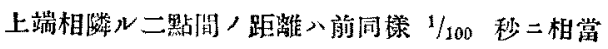
$>0$

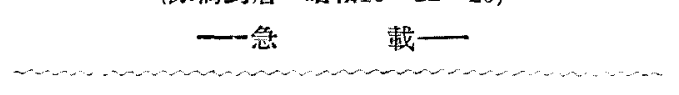

